\title{
Specific Nonpeptide Inhibitors of Puromycin-Sensitive Aminopeptidase with a 2,4(1H,3H)-Quinazolinedione Skeleton
}

\author{
Hiroki Kakuta, Aya Tanatani, Kazuo Nagasawa, and Yuichi Hashimoto* \\ Institute of Molecular \& Cellular Biosciences, The University of Tokyo; 1-1-1 Yayoi, Bunkyo-ku, Tokyo 113-0032, Japan. \\ Received June 13, 2003; accepted July 26, 2003
}

\begin{abstract}
Potent, specific, chemically stable and non-peptide/small-molecular inhibitors of puromycin-sensitive aminopeptidase, such as 3-(2,6-diethylphenyl)-2,4(1H,3H)-quinazolinedione (PAQ-22, 5), were prepared by the structural development of a potent PSA inhibitor, 2-(2,6-diethylphenyl)-1,2,3,4-tetrahydroisoquinoline-1,3-dione (PIQ-22, 4). The design was carried out partly by applying electrostatic potential field information obtained from PIQ-22 (4) and its derivatives based on thalidomide (2). This information revealed that a positive electrostatic potential field around the benzylic methylene in the tetrahydroisoquinoline ring is necessary for potent activity. Lineweaver-Burk plot analysis showed that PAQ-22 (5) and its derivatives inhibit puromycin-sensitive aminopeptidase (PSA) in a non-competitive manner. These potent and specific PSA inhibitors showed dose-dependent cell invasion-inhibitory activity in a Matrigel assay using mouse melanoma B16F10/L5 cells, in spite of their low cell toxicity.
\end{abstract}

Key words puromycin-sensitive aminopeptidase; inhibitor; quinazolinedione; structure-activity relationship

Neutral alanine-aminopeptidases (NAPs), which degrade tissue barriers and regulate cell adhesion and mobility, are thought to play important roles in the malignant metastatic cascade, including the tumor cell invasion step, i.e., the passage of tumor cells through connective tissue barriers, which consist of various adhesive molecules such as fibronectin, laminin, and so on. ${ }^{1-15)}$ In the course of our structural development studies of thalidomide, ${ }^{16-20)}$ we reported the preparation and structure-activity relationships of novel small-molecular nonpeptide aminopeptidase inhibitors with a cyclic imide skeleton. ${ }^{20-27)}$ Among them, 2-(2,6-diethylphenyl)1,2,3,4-tetrahydro-isoquinoline-1,3-dione (4: PIQ-22) (Fig. $1)^{20,21,23-27)}$ showed specific and more potent NAP-inhibitory activity than bestatin (3) ${ }^{13)}$ (Fig. 1) in a well-established assay system for aminopeptidase N-inhibitory activity (APN: EC 3.4.11.2/CD13), i.e., measuring 7-amino-4-methylcoumarin (AMC) liberated from L-methylcoumarylamide $(\text { Ala-AMC) })^{12,13)}$ with intact human acute lymphoblastic leukemia MOLT-4 cells. ${ }^{11,23-27)}$ This enzyme is thought to play a crucial role in matrix degradation and invasion by tumor cells. However, our previous studies revealed that $\mathbf{4}$ does not inhibit the activity of authentic APN, and that the true target enzyme of $\mathbf{4}$ is puromycin-sensitive aminopeptidase (PSA: EC 3.4.11.14). ${ }^{20,21,26,27)}$

PSA, which was purified as a candidate enkephalinase by Hersh and McKelvy in 1981, ${ }^{28)}$ is a single chain protein of 99 $\mathrm{kDa}^{9,28)}$ that hydrolyzes N-terminal amino acids with a preference for basic and hydrophobic residues. ${ }^{29-32)}$ This enzyme is an exopeptidase containing a $\mathrm{Zn}^{2+}$ ion in its catalytic site. ${ }^{28-30)}$ It is distributed in the brain (especially the hippocampus), the central nervous system (CNS), the heart, skeletal muscles, kidney, placenta, and testicles. ${ }^{29,30)}$ In cells, PSA is localized both to the nucleus and to the cytoplasm. ${ }^{30,33,34)}$ The activity of PSA is inhibited by puromycin (1) (Fig. 1) at a low concentration, ${ }^{28)}$ but $\mathbf{1}$ is not a specific inhibitor of PSA. This is because the amino acid sequences recognized by $\mathbf{1}$, i.e., the catalytic site for hydrolysis and the substrate-binding site, are similar among various NAPs. ${ }^{35}$ )

Recently, it was reported that PSA gene-deficient mice obtained by a gene-trapping method show increased anxiety and impaired pain response. ${ }^{35)}$ On the other hand, the degradation of enkephalins was not detected in these mice. ${ }^{35)}$ Thus, the physiological function of PSA is unclear. In addition, the lack of specific inhibitors has made the elucidation of the physiological function of PSA difficult, ${ }^{36)}$ and therefore, development of PSA-specific inhibitors which can be used as biological/biochemical probes is important.

Though PIQ-22 (4) is a potent and specific inhibitor of PSA, it is chemically labile and easily oxidized at the benzylic methylene position in the tetrahydroisoquinoline ring to give an inactive tricarbonyl derivative, ${ }^{20,26,27)}$ which makes $\mathbf{4}$ unsuitable for use as a biological/biochemical tool. Therefore, we designed and developed chemically stable PSA specific inhibitors, 3-(2,6-diethylphenyl)-2,4(1H,3H)-quinazolinedione (5: PAQ-22) and $N$-(2,6-diethylphenyl)-2-amino4H-3,1-benzoxazin-4-one (6: PAZOX-22) (Fig. 1), partly based on electrostatic potential field considerations. ${ }^{37)} \mathrm{We}$ also developed fluorescent analogs of $\mathbf{5}$ which can be used as probes to visualize PSA in living cells, i.e., 3-(9-anthracenyl)-2,4(1H,3H)-quinazolinedione (7: ANTAQ) and 3(2,6-diethyl-4-dansylaminophenyl)-1-methyl-2,4(1H,3H)quinazolinedione (8: DAMPAQ-22) (Fig. 1). ${ }^{38)}$
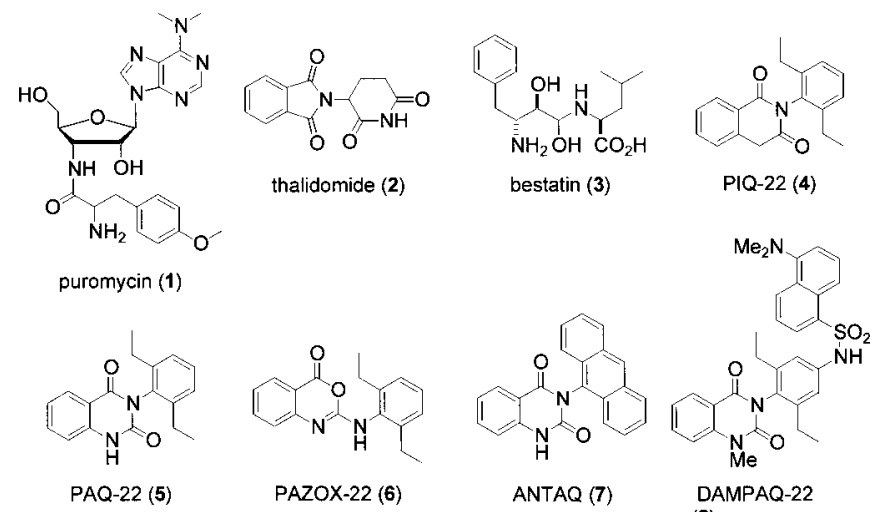

DAMPAQ-22

Fig. 1. Structures of Puromycin (1), Thalidomide (2), Bestatin (3), PSASpecific Inhibitors (PIQ-22: 4, PAQ-22: 5, PAZOX-22: 6), and Fluorescent Probes for Visualization of PSA (ANTAQ: 7, DAMPAQ-22: 8) 
Here, we describe in detail the design of PAQ-22 (5) and its derivatives, their structure-activity relationship, and their inhibitory activity towards cell invasion.

\section{Results and Discussion}

Design of PAQ-22 (5): Structure-Activity Relationship Studies of $\mathrm{N}$-2,6-Diethylphenyl(homo)phthalimides with Electrostatic Potential Field Maps Typical previous results regarding the structure-activity relationship are illustrated in Fig. 2..$^{20,26,27)}$ The ring reduction of PIQ-22 (4), i.e., $N$-2,6-diethylphenylphthalimide (14), resulted in the disap- pearance of the PSA-inhibitory activity. However, introduction of an electron-donating group such as an amino $(\mathbf{1 0}, \mathbf{1 1})$ or a hydroxyl $(12,13)$ group into the phthalimide moiety of the inactive compound $\mathbf{1 4}$ resulted in the reappearance of the activity. On the other hand, introduction of an electron-withdrawing nitro group $(\mathbf{1 5}, \mathbf{1 6})$ had no effect on the activity. The tricarbonyl derivative of PIQ-22 (4), i.e., 17, which is also an auto-oxidation product of $\mathbf{4}$ in a protic solvent under air with exposure to daylight, is completely inactive toward PSA. The difluorinated analog of 4 , i.e., 18, which was synthesized in order to prevent auto-oxidization at the benzylic

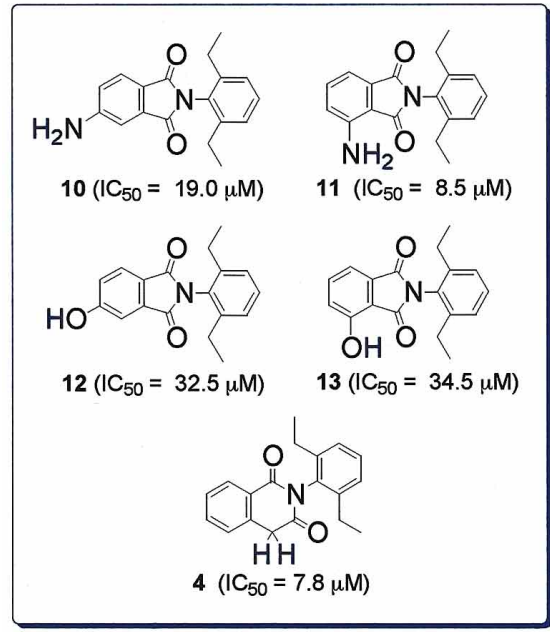

active

10

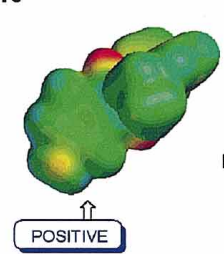

PIQ-22 (4)
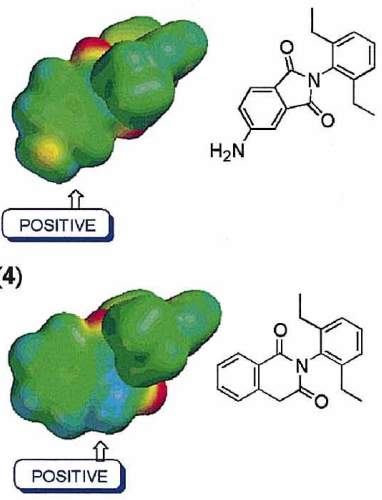

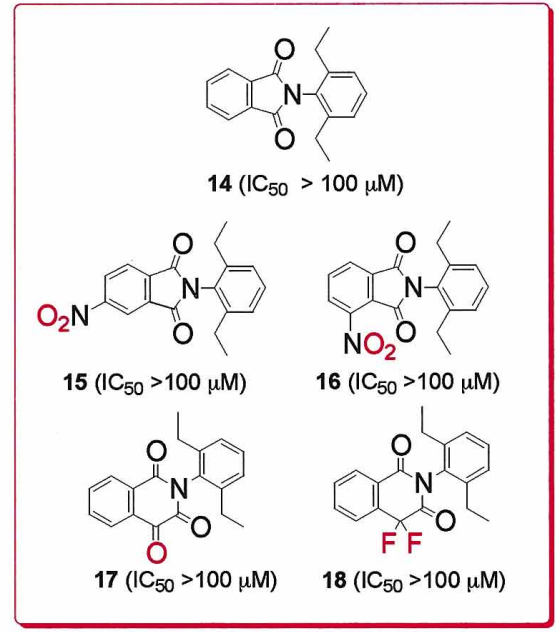

inactive

15

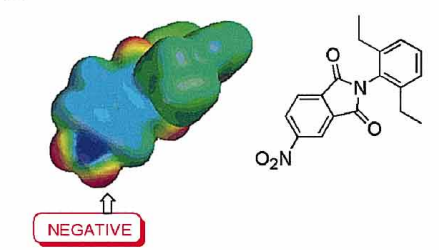

17

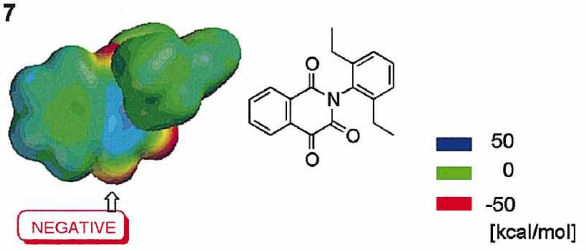

Fig. 2. PSA-Inhibitory Activitiy of $N$-Phenyl(homo)phthalimide Derivatives and Electrostatic Potential Field Maps of Selected Compounds Positions indicated by arrows are designated as the south-western part in this paper.

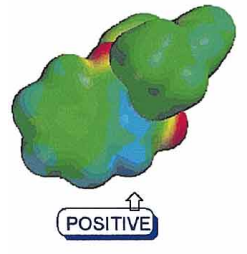

PAQ-22 (5)

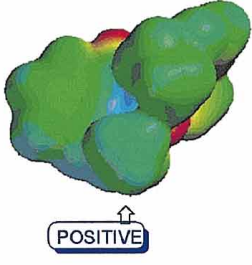

PAQ-22E (22b)

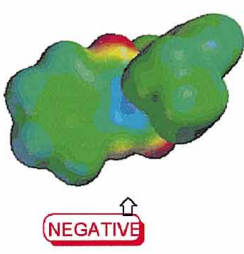

$\mathrm{POQ}-22$ (25)

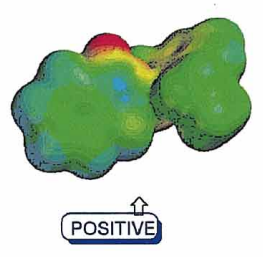

PAZOX-22 (6)

$$
\begin{gathered}
50 \\
0 \\
-50 \\
{[\mathrm{kcal} / \mathrm{mol}]}
\end{gathered}
$$

Fig. 6. Electrostatic Potential Field Maps of PAQ-22 (5) and Its Derivatives 
methylene moiety in the isoquinoline ring, is also completely inactive.

Comparison of the structures of active compounds with those of inactive/weakly active compounds, i.e., amino/hydroxyl-containing arylphthalimide analogs $(\mathbf{1 0}$ - $\mathbf{1 3})$ versus inactive derivatives $(\mathbf{1 4}-\mathbf{1 7})$, led us to guess that the active compounds possess a common feature. We focused on the electrostatic potential around the benzylic methylene moiety of the homophthalimide analogs $(4,17,18$ : colored moieties in structural formulae in the upper panels in Fig. 2, and regions indicated by arrows in the lower part of Fig. 2) and the corresponding parts of phthalimide analogs (10-16: also colored or indicated by arrows in Fig. 2). These parts appear to be located at roughly similar positions in relation to the fixed $N$-2,6-diethylphenyl group, i.e., the bottom left, when the electrostatic potential field maps of the compounds are drawn as presented in the lower part of Fig. 2. In this paper, the position is designated as the "southwestern part" (Fig. 2). The electrostatic potential surfaces of these molecules ${ }^{39-43)}$ generated by means of computer calculations ${ }^{43)}$ are shown in the lower part of Fig. 2 .

All of the active compounds listed in Fig. 2 can be regarded as possessing a positive electrostatic field around the southwestern part of the molecules. On the other hand, all of the inactive compounds listed in Fig. 2 possess a negative electrostatic field at the corresponding location.

The results suggested that a positive electrostatic field around the benzylic methylene of the tetrahydroisoquinoline ring, at which auto-oxidation occurs in the case of PIQ-22 (4), is necessary for potent PSA-inhibitory activity. Based on this consideration, we designed $N$-2,6-diethylphenyl-2,4$(1 H, 3 H)$-quinazolinedione (PAQ-22, 5) (Fig. 3).

Syntheses and PSA-Inhibitory Activity of PAQ-22 (5) and Related Analogs PAQ-22 (5) was prepared by the condensation of 2,6-diethylaniline (19) and methyl anthranilate in the presence of triphosgene by the method previously reported, as shown in Fig. 4. ${ }^{37,45)}$ An alternative preparation of 5 was performed through reaction of the amide $\mathbf{2 4}$ and triphosgene in 1,2-dichloroethene in 79\% yield. ${ }^{45)} \mathrm{N}$-Alkylated PAQ-22s $(\mathbf{2 2 a}-\mathbf{e})$ were prepared by treatment with sodium hydride in dimethylformamide, followed by reaction of the resulting salt with an alkyl halide at room temperature.

A structural isomer of PAQ-22 (5), $N$-(2,6-diethylphenyl)2-amino-4H-3,1-benzoxazinone (6: PAZOX-22), which can have a benzylic proton at the corresponding position through protonation or tautomerization from the imine form to the amine form, was prepared from the ureido intermediate $\mathbf{2 1 b}$ under acidic conditions (Fig. 4). ${ }^{37,45)}$

A derivative oxygenated at the corresponding benzylic $\mathrm{NH}$ position, 3-(2,6-diethylphenyl)-2H-1,3-benzoxazine-2,4(3H)quinazolinedione (26: POQ-22), was prepared according to Brown et al. ${ }^{46)}$ Briefly, a solution of $N$-(2,6-diethylphenyl)-2hydroxybenzamide 25 in pyridine at $0{ }^{\circ} \mathrm{C}$ was treated with ethyl chloroformate, then the mixture was allowed to warm to room temperature and heated to reflux (Fig. 5).

The structures of the prepared compounds were confirmed by ${ }^{1} \mathrm{H}-\mathrm{NMR}$, mass spectroscopy, and elemental analysis, which gave appropriate analytical values.

Inhibition of PSA by the compounds was assessed by measuring 7-amino-4-methylcoumarin (AMC) liberated from Lmethylcoumarylamide (Ala-AMC) using intact human acute lymphoblastic leukemia MOLT-4 cells..$^{1,26,27,37)}$ In order to examine the specificity of PSA-inhibitory activity, inhibition of another aminopeptidase, APN, by the compounds was also assessed by measuring AMC liberated from Ala-AMC with human promyelocytic leukemia HL-60 cells. All experiments were performed at least in duplicate.

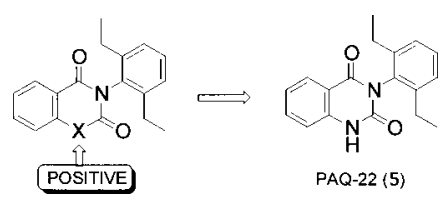

Fig. 3. Design of PAQ-22 (5)

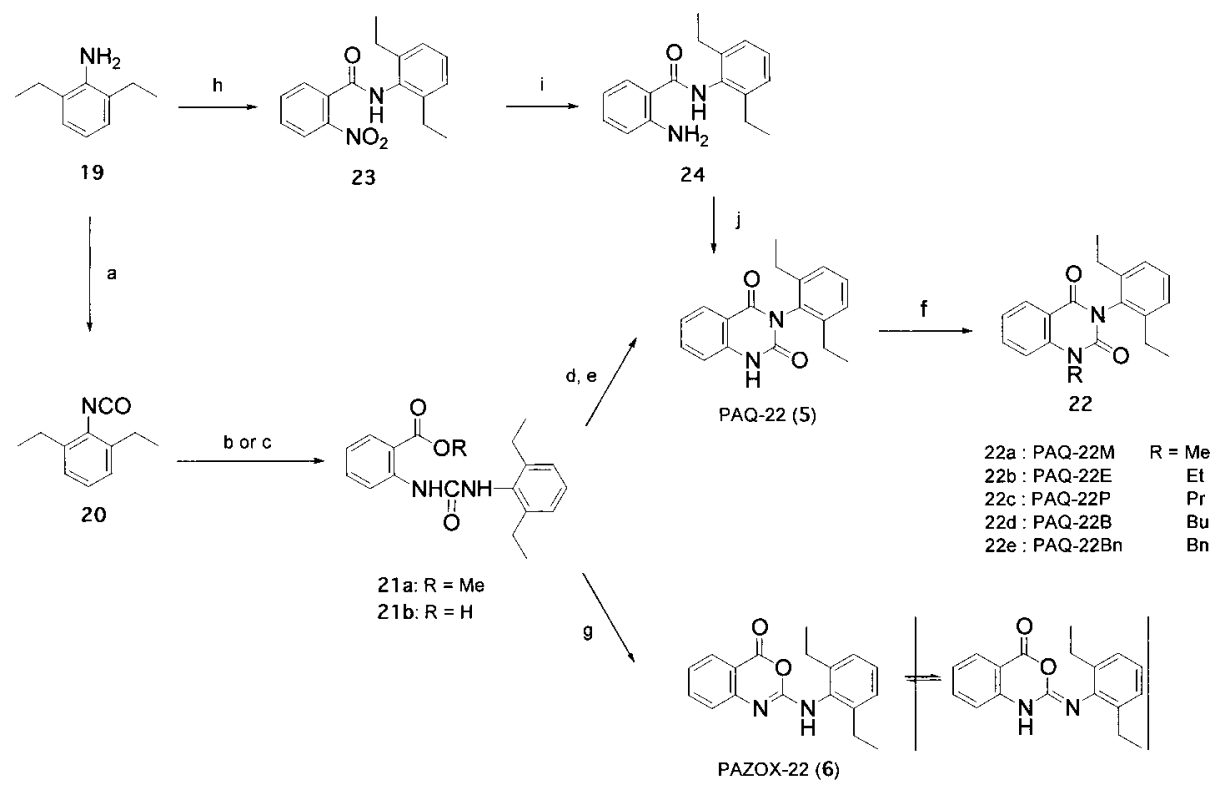

(a) Triphosgene, triethylamine, 1,2-dichloroethane (q.y.). (b) Methyl anthranilate, Et ${ }_{2} \mathrm{O}$. (c) Anthranilic acid, THF. (d) NaOHaq, EtOH. (e) HClaq (65\%, 3 steps). (f) NaH, DMF, alkyl halide (62\%-q.y.). (g) $\mathrm{H}_{2} \mathrm{SO}_{4}$ aq, $\mathrm{NaHCO}_{3}\left(40 \%, 2\right.$ steps). (h) 2-Nitrobenzoyl chloride, pyridine, $\mathrm{CHCl}_{3}(84 \%)$. (i) $\mathrm{H}_{2}, 10 \%$ Pd/C, EtOAc (q.y.). (j) Triphosgene, triethylamine, 1,2-dichloroethane $(79 \%)$.

Fig. 4. Preparation of PAQ-22 (5) and Its Derivatives 


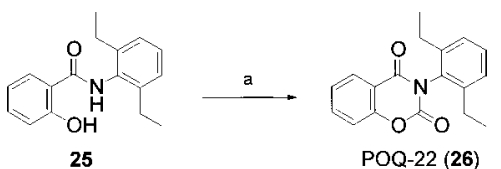

(a) Ethyl chloroformate, pyridine (39\%).

Fig. 5. Preparation of POQ-22 (26)

Table 1. Aminopeptidase-Inhibitory Activity of PAQ-22 Derivatives

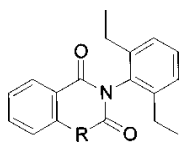

\begin{tabular}{|c|c|c|c|}
\hline & \multirow{2}{*}{$\mathrm{R}$} & PSA IC 50 & $\mathrm{APN} \mathrm{IC}{ }_{50}$ \\
\hline & & \multicolumn{2}{|c|}{$(\mu \mathrm{M})$} \\
\hline 5: PAQ-22 & $\mathrm{NH}$ & 3.8 & $>100$ \\
\hline 22a: PAQ-22M & $\mathrm{NMe}$ & 3.4 & $>100$ \\
\hline 22b: PAQ-22E & NEt & 0.7 & $>100$ \\
\hline 22c: $\mathrm{PAQ}-22 \mathrm{P}$ & NPr & 0.6 & $>100$ \\
\hline 22d: PAQ-22B & $\mathrm{NBu}$ & 0.9 & $>100$ \\
\hline 22e: PAQ-22Bn & NBn & 1.1 & $>100$ \\
\hline 26: POQ-22 & $\mathrm{O}$ & 53.4 & $>100$ \\
\hline 6: PAZOX-22 & - & 9.8 & $>100$ \\
\hline 1: Puromycin & - & 0.6 & 4.8 \\
\hline
\end{tabular}

The inhibitory activities are listed as $\mathrm{IC}_{50}$ values in Table 1. PAQ-22 (5) and $N$-alkylated PAQ-22(s) (22a-e) have potent inhibitory activity towards PSA, but no inhibitory activity towards APN. PAZOX-22 (6) showed a similar level of activity to PAQ-22, whereas POQ-22 (26) had only low inhibitory activity towards PSA.

Electrostatic potential surfaces of these molecules were generated by means of computer calculations. ${ }^{44)}$ The results are shown in Fig. 6. POQ-22 (26), whose PSA-inhibitory activity is low, shows a negative electrostatic field at the southwestern part of the molecule. On the other hand, PAQ-22 (5), $N$-alkylated PAQ-22(s) and PAZOX-22 (6), which have potent PSA-inhibitory activity, show positive electrostatic fields around the corresponding region. The results are consistent with our hypothesis, i.e., the requirement of a positive electrostatic field at the southwestern part for inhibitory activity. Moreover, PAQ-22 (5), and $N$-alkylated PAQ-22(s) (22a-e) were chemically quite stable under conditions where PIQ-22 (4) was completely auto-oxidized.

Structural Development of PAQ-22 (5): Effects of Derivatization of the Quinazolinedione Moiety and $\mathrm{N}$ Phenyl Moiety To reach a better understanding of the structure-activity relationships of PAQ-22-type PSA inhibitors, we prepared other PAQ-22 derivatives. First, we replaced the carbonyl group of PAQ-22 (5) with a thiocarbonyl group or a methylene group (Fig. 7, Table 2). Next we introduced amino/nitro groups into the quinazolinedione aromatic ring of PAQ-22 (5) (Fig. 8, Table 3). The role of the 2,6-diethyl groups on the side aromatic ring of the PAQ-22 (5) was also examined (Table 4).

Preparation of 27, which has a thiocarbonyl group at the 2position, was achieved by treatment of the amide compound 24 with carbon disulfide and DBU in DMF (Fig. 7-i). The 2-

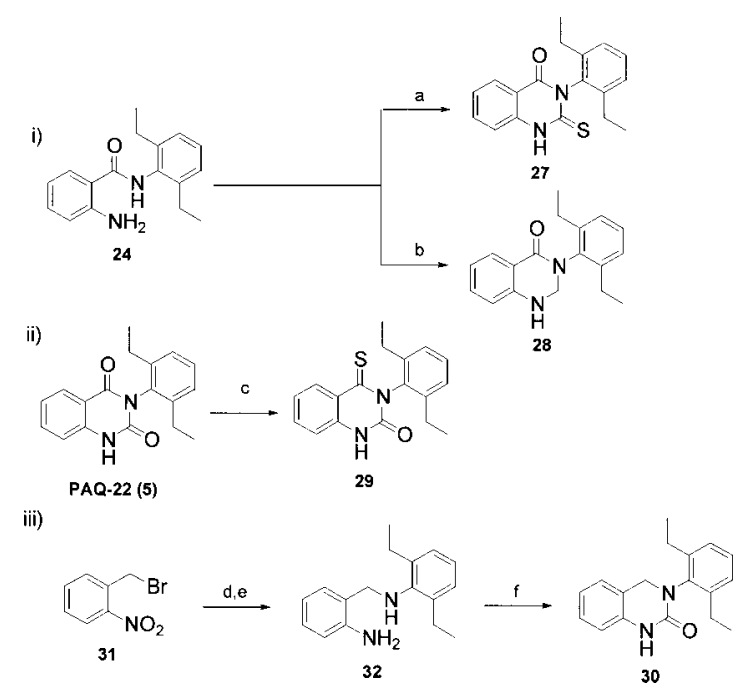

(a) $\mathrm{CS}_{2}$, DBU, DMF (78\%). (b) $\mathrm{NaOH}$, formalin, $\mathrm{EtOH}, 60^{\circ} \mathrm{C}(90 \%)$. (c) $\mathrm{P}_{4} \mathrm{~S}_{10}$, xylene (88\%). (d) 2,6-Diethylaniline, $\mathrm{K}_{2} \mathrm{CO}_{3}$, DMF. (e) $\mathrm{FeO}(\mathrm{OH}), \mathrm{NH}_{2} \mathrm{NH}_{2}, \mathrm{MeOH} 60^{\circ} \mathrm{C}$ $\left(98 \%, 2\right.$ steps). (f) $\left(\mathrm{CCl}_{3} \mathrm{O}\right)_{2} \mathrm{CO}, \mathrm{Et}_{3} \mathrm{~N}, 1,2$-dichloroethane, reflux $(83 \%)$.

Fig. 7. Synthesis of Analogs Related to PAQ-22 (5)

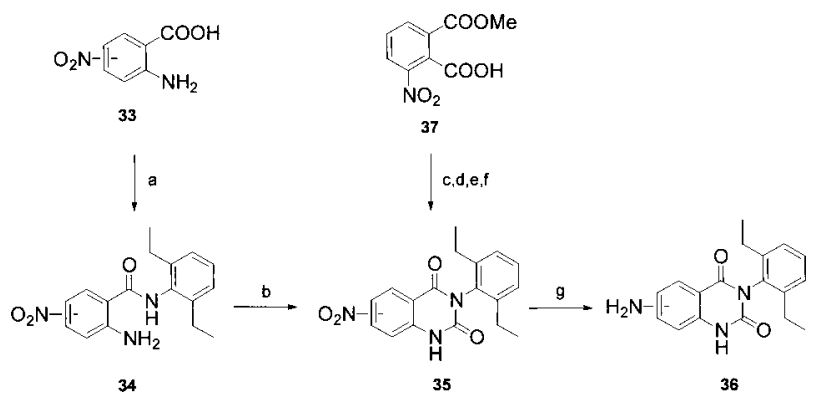

(a) 2,6-Diethylaniline, EDC, HOBt, DMF (65-80\%). (b) $\left(\mathrm{CCl}_{3} \mathrm{O}\right)_{2} \mathrm{CO}, \mathrm{Et}_{3} \mathrm{~N}, 1,2$ dichloroethane, reflux (70-80\%). (c) $\mathrm{ClCO}_{2} \mathrm{Et}, \mathrm{Et}_{3} \mathrm{~N}$, THF, $-20^{\circ} \mathrm{C}$, (d) $\mathrm{NaN}_{3} / \mathrm{PhCH}_{3}$, reflux. (e) 2,6-Diethylaniline. (f) $\mathrm{NaOH}, \mathrm{H}_{2} \mathrm{O} / \mathrm{EtOH} ; \mathrm{HCl} / \mathrm{H}_{2} \mathrm{O}\left(85 \%, 4\right.$ steps). (g) $\mathrm{H}_{2}$, Pd-C, EtOH (80\%-q.y.).

Fig. 8. Synthesis of Nitro/Amino-Substituted PAQ-22 Derivatives

dihydro derivative, 28, was prepared by treatment of $\mathbf{2 4}$ with formalin and sodium hydroxide in ethanol (Fig. 7-i). The preparation of the 4-thiocarbonyl derivative, 29, was achieved by treatment of PAQ-22 (5) with phosphorus sulfide in xylene under reflux for $10 \mathrm{~h}$ (Fig. 7-ii). The 4-dihydro ana$\log$, 30, was prepared by treatment of 2-amino- $N$-(2,6-diethylphenyl)benzenemethanamine (32), which was prepared from 2-nitrobenzylbromide (31) and 2,6-diethylaniline (19), with triphosgene in 1,2-dichloroethane (Fig. 7-iii). The nitrosubstituted derivatives of PAQ-22 (5), 35a and $\mathbf{b}$, were prepared by the treatment of $\mathbf{3 4}$ with triphosgene in 1,2dichloroethane (Fig. 8). The regio-isomer, 35c, was prepared by the method described by Canonne et al. ${ }^{47)}$ The resulting compounds were reduced by catalytic hydrogenation over $\mathrm{Pd} / \mathrm{C}$ in ethanol to give amino derivatives, 36a-c (Fig. 8). Compounds 38-45 were obtained by the method used for the preparation of PAQ-22 (5), with the corresponding aniline $\operatorname{analog}(\mathrm{s})$. The PSA-inhibitory activity of prepared compounds is shown in terms of $\mathrm{IC}_{50}$ values in Tables $2-4$.

As shown in Table 2, among compounds 27-31, only $\mathbf{2 7}$ showed potent PSA-inhibitory activity, which is comparable to that of PAQ-22 (5). All of the other compounds (28-31) are less potent than PAQ-22 (5) or inactive, suggesting that 
Table 2. Aminopeptidase (PSA and APN)-Inhibitory Activity of PAQ-22 (5) and Related Compounds

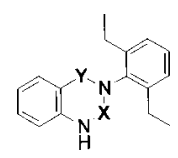

\begin{tabular}{lllrl}
\hline \hline & & & PSA IC $_{50}$ & APN IC $_{50}$ \\
\cline { 3 - 5 } & & & & \multicolumn{2}{c}{$(\mu \mathrm{M})$} \\
& & & 3.8 & $>100$ \\
$\mathbf{5 : ~ P A Q - 2 2 ~}$ & $\mathrm{CO}$ & $\mathrm{CO}$ & 3.8 & $>100$ \\
$\mathbf{2 7}$ & $\mathrm{CS}$ & $\mathrm{CO}$ & 25.3 & $>100$ \\
$\mathbf{2 9}$ & $\mathrm{CO}$ & $\mathrm{CS}$ & 26.7 & $>100$ \\
$\mathbf{2 8}$ & $\mathrm{CH}_{2}$ & $\mathrm{CO}$ & $>100$ & $>100$ \\
$\mathbf{3 0}$ & $\mathrm{CO}$ & $\mathrm{CH}_{2}$ & & \\
\hline
\end{tabular}

Table 3. Aminopeptidase (PSA and APN)-Inhibitory Activity of PAQ-22 Derivatives

$$
\text { (1) }
$$

\begin{tabular}{cccc}
\hline \hline & & PSA IC $_{50}$ & APN IC $_{50}$ \\
\cline { 3 - 4 } & & \multicolumn{2}{c}{$(\mu \mathrm{M})$} \\
\hline 5: PAQ-22 & $\mathrm{H}$ & 3.8 & $>100$ \\
35a & $6-\mathrm{NO}_{2}$ & 76.8 & $>100$ \\
35b & $7-\mathrm{NO}_{2}$ & 33.4 & $>100$ \\
35c & $8-\mathrm{NO}_{2}$ & 14.6 & $>100$ \\
36a & $6-\mathrm{NH}_{2}$ & 10.0 & $>100$ \\
36b & $7-\mathrm{NH}_{2}$ & 6.6 & $>100$ \\
36c & $8-\mathrm{NH}_{2}$ & 0.5 & $>100$ \\
\hline
\end{tabular}

the carbonyl groups are important for potent PSA-inhibitory activity. The compounds with a carbonyl group at the 4-position $(\mathbf{2 7}, \mathbf{2 8})$ are more potent inhibitors than the corresponding compounds possessing a carbonyl group at the 2-position (29, 30, respectively).

Concerning the effects of a substituent on the aromatic ring of the quinazolinedione moiety, amino derivatives $(36 \mathbf{a}-\mathbf{c})$ possess more potent PSA-inhibitory activity than the corresponding nitro derivatives $(\mathbf{3 5 a}-\mathbf{c})$ (Table 3$)$. Among the compounds listed in Table 3, 36c shows the most potent activity. This result suggests that a positive electrostatic field near the 2-carbonyl group is important for potent inhibitory activity. This information led us to design and synthesize a ring-closure derivative, $\mathbf{3 8}$, which also showed more potent PSA-inhibitory activity than PAQ-22 (5) (Table 4). The aromatic ring on the side chain seems to be necessary for potent activity, since $\mathbf{3 9}$ showed no inhibitory activity (Table 4).

Concerning the effects of 2,6-dialkyl substituents on the $\mathrm{N}$-phenyl group, the non-alkylated derivative, 40, is almost inactive (Table 4). Introduction of alkyl or methoxyl groups at the ortho positions $(\mathbf{5}, \mathbf{4 1}-\mathbf{4 3})$ resulted in the appearance of PSA-inhibitory activity. The activity decreased in the order of: PAQ-22 (5) $>\mathbf{4 3}>\mathbf{4 2}>\mathbf{4 1}>\mathbf{4 0}$, indicating the superiority of an ethyl group over other alkyl and methoxyl
Table 4. Aminopeptidase (PSA and APN)-Inhibitory Activity of 38-45
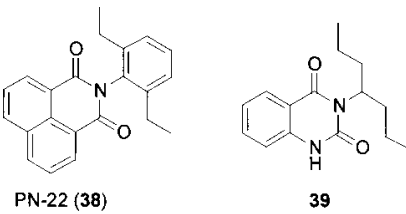

\begin{tabular}{lcc}
\hline \hline & PSA IC $_{50}$ & APN IC $_{50}$ \\
\cline { 2 - 3 } & \multicolumn{3}{c}{$(\mu \mathrm{M})$} \\
\hline PN-22(38) & 0.8 & $>100$ \\
39 & $>100$ & $>100$ \\
\hline
\end{tabular}

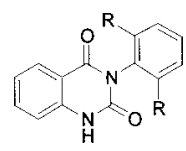

\begin{tabular}{|c|c|c|c|}
\hline & \multirow{2}{*}{$\mathrm{R}$} & PSA $\mathrm{IC}_{50}$ & $\mathrm{APN} \mathrm{IC} \mathrm{I}_{50}$ \\
\hline & & \multicolumn{2}{|c|}{$(\mu \mathrm{M})$} \\
\hline 40: PAQ-00 & $\mathrm{H}$ & $>100$ & $>100$ \\
\hline 41: PAQ-11 & $\mathrm{Me}$ & 78.3 & $>100$ \\
\hline 5: PAQ-22 & Et & 3.8 & $>100$ \\
\hline 42: PAQ-33 & $\mathrm{iPr}$ & 7.0 & $>100$ \\
\hline \multirow[t]{3}{*}{43} & $\mathrm{MeO}$ & 4.5 & $>100$ \\
\hline & \multirow{2}{*}{$\mathrm{R}^{\prime}$} & PSA $\mathrm{IC}_{50}$ & $\mathrm{APN} \mathrm{IC}{ }_{50}$ \\
\hline & & \multicolumn{2}{|c|}{$(\mu \mathrm{M})$} \\
\hline 44 & $\mathrm{H}$ & 37.0 & $>100$ \\
\hline 45 & $\mathrm{OMe}$ & 1.0 & $>100$ \\
\hline
\end{tabular}

groups, as was the case for PIQ-22 (4) derivatives reported previously (Table 4). ${ }^{23-27)}$ These results suggest that moderately bulky substitution and a hydrophobic environment around the nitrogen atom in the quinazolinedione moiety and perpendicular orientation of the $N$-aryl group with respect to the plane of the quinazolinedione moiety are critical factors for potent PSA-inhibitory activity. The information concerning the structure-activity relationship of PAQ-22 derivatives described above is summarized in Fig. 9.

PSA Inhibition Mode of PAQ-22 and Its Derivatives Because there is no obvious structural relationship between PAQ-22 (5) and puromycin (1), the mode of inhibition elicited by these two inhibitors, as well as bestatin (3), was analyzed by Lineweaver-Burk plot analysis. ${ }^{20,26,27)}$ The analysis clearly indicates that PAQ-22 (5) and its derivatives inhibit PSA in a non-competitive manner, while puromycin (1) and bestatin (3) inhibit PSA in a competitive manner. The results suggest that PAQ-22 (5) and its derivatives do not act 


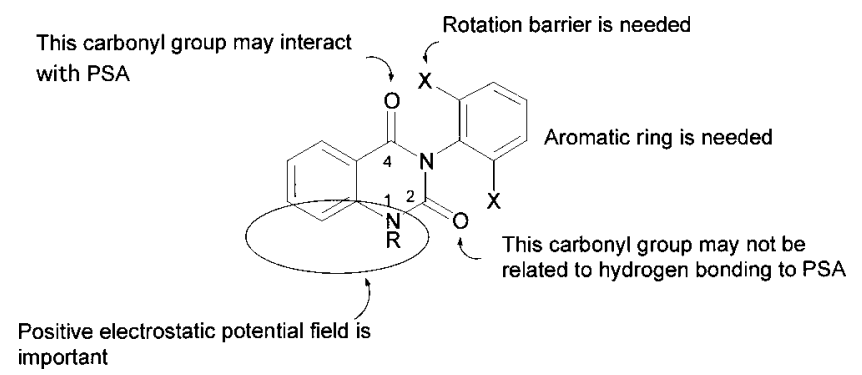

Fig. 9. Important Factors for Potent and Specific PSA Inhibitors

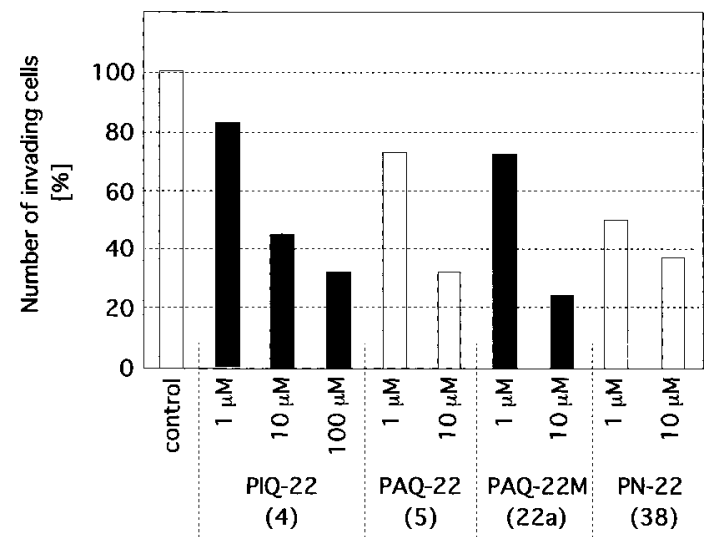

Fig. 10. Effects of PSA Inhibitors on Invasion of B16F10 Cells into Matrigel

as substrate-mimics, but bind at a specific site of PSA which is not the substrate-binding site, while puromycin (1) and bestatin (3) act as substrate-mimics. Identification of the binding site of PAQ-22 (5) and its derivatives is in progress.

Cell Invasion-Inhibiting Activity of PAQ-22 and Its Derivatives First we examined the cytotoxicity of our PSA inhibitors. Since puromycin (1) induces apoptosis, PSA is thought to participate in proteolytic events that are essential for cell growth and viability. ${ }^{48}$ ) The cell proliferation-inhibitory activity of our PSA inhibitors were examined using MOLT- 4 cells with WST-1. However, none of the inhibitors examined showed significant cell proliferation-inhibitory activity at the concentration of $10 \mu \mathrm{M}$. Only slight proliferation inhibitory activity was observed for several compounds at the concentration of $100 \mu \mathrm{M}$ (data not shown). On the other hand, puromycin (1) showed potent cell proliferation-inhibitory activity even at the concentration of $1 \mu \mathrm{M}$ : the efficacy was $48 \%$ at $1 \mu \mathrm{M}$, and $98 \%$ at $10 \mu \mathrm{M}$. The results suggest that PSA is not closely associated with proliferation, and the cell proliferation-inhibitory activity elicited by puromycin (1) can be attributed to the characteristic inhibition of protein synthesis in ribosomes by puromycin, because of the structural similarity of 1 to aminoacyl- $t$ RNA.

Next, we examined the cell invasion-inhibiting activity of our PSA-inhibitors. As already reported, PSA has been proposed to be a target molecule of cell invasion inhibitors. ${ }^{23-27)}$ Tumor cell invasion inhibition was assessed by counting mouse metastatic tumor cells (B16F10/L5 mouse melanoma cells) that invaded into Matrigel-coated filters, as described by Albini et al. ${ }^{49)}$ Each sample was tested in triplicate, and the mean values for selected compounds are shown in Fig. 10 .
As shown in Fig. 10, PIQ-22 (4), PAQ-22 (5), PAQ-22M (22a) and PN-22 (38) exhibited potent and dose-dependent cell invasion-inhibiting activity. Compared with PIQ-22 (4), the PSA inhibitors PAQ-22 (5), PAQ-22M (22a) and PN-22 (38), which are all more potent than PIQ-22 (4), showed more potent cell invasion-inhibitory activity than 4 . Thus, potent cell invasion-inhibiting activity of the compounds coincides with potent PSA inhibition, suggesting that PSA plays a role in cell mobility.

\section{Conclusion}

In conclusion, we created potent, specific, chemically stable and non-peptide/small-molecular PSA inhibitors, such as PAQ-22 (5), by structural development of a PSA inhibitor, PIQ-22 (4). Design was based on electrostatic potential field information, gathered from PIQ-22 (4) and its derivatives. The new PSA inhibitors showed potent and dose-dependent tumor cell invasion-inhibitory activity, despite their low cell toxicity. Our PSA inhibitors should be useful tools for investigation of the molecular/cell level mechanism(s) of action and the physiological roles of PSA.

\section{Experimental}

Abbreviations $\mathrm{AcOH}$, acetic acid; $\mathrm{AcONa}$, sodium acetate; DMF, $\mathrm{N}, \mathrm{N}$ dimethylformamide; BINAP, 2,2'-bis(diphenylphosphino)-1,1'-binaphthyl; DBU, 1,8-diazabicyclo[5.4.0]undec-7-ene; DMSO, dimethyl sulfoxide; EDC, 1-(3-dimethylaminopropyl)-3-ethylcarbodiimide hydrochloride; $\mathrm{EtOH}$, ethanol; EtOAc, ethyl acetate; $\mathrm{Et}_{3} \mathrm{~N}$, triethylamine; Hex, $n$-hexane; $\mathrm{HOBt}$, 1-hydroxybenzotriazole; $\mathrm{MeOH}$, methanol

General Comments Melting points were determined with a Yanagimoto hot-stage melting point apparatus and are uncorrected. Elemental analyses were carried out in the Microanalytical Laboratory, Faculty of Pharmaceutical Sciences, University of Tokyo, and results were within $\pm 0.3 \%$ of the theoretical values. NMR spectra were recorded on a JEOL JNM- $\alpha-500$ $(500 \mathrm{MHz})$ spectrometer.

2-(2,6-Diethylphenyl)-1,2,3,4-tetrahydroisoquinoline-1,3,4-trione (17) $\mathrm{mp} 163-165^{\circ} \mathrm{C} ;{ }^{1} \mathrm{H}-\mathrm{NMR}\left(500 \mathrm{MHz}, \mathrm{CDCl}_{3}\right) \delta: 8.41(\mathrm{dd}, 1 \mathrm{H}, J=7.5,1.0$ $\mathrm{Hz}), 8.34$ (dd, $1 \mathrm{H}, J=7.5,1.0 \mathrm{~Hz}), 7.97(\mathrm{td}, 1 \mathrm{H}, J=7.5,1.0 \mathrm{~Hz}), 7.92$ (td, $1 \mathrm{H}$, $J=7.5,1.0 \mathrm{~Hz}), 7.42(\mathrm{t}, 1 \mathrm{H}, J=7.5 \mathrm{~Hz}), 7.26(\mathrm{~d}, 2 \mathrm{H}, J=7.5 \mathrm{~Hz}), 2.41(\mathrm{q}, 4 \mathrm{H}$, $J=7.5 \mathrm{~Hz}), 1.14(\mathrm{t}, 6 \mathrm{H}, J=7.5 \mathrm{~Hz})$; FAB-MS $m / z: 308(\mathrm{M}+\mathrm{H})^{+}$; IR $(\mathrm{KBr}$, $\mathrm{cm}^{-1}$ ) 1680, 1280, 1260; Anal. Calcd for $\mathrm{C}_{19} \mathrm{H}_{17} \mathrm{NO}_{3}: \mathrm{C}, 74.24 ; \mathrm{H}, 5.59 ; \mathrm{N}$, 4.56. Found: C, 74.32; $\mathrm{H}, 5.84 ; \mathrm{N}, 4.43$.

2-(2,6-Diethylphenyl)-4,4-difluoro-1,2,3,4-tetrahydroisoquinoline-1,3dione (18) $\mathrm{mp} 122-123^{\circ} \mathrm{C} ;{ }^{1} \mathrm{H}-\mathrm{NMR}\left(500 \mathrm{MHz}, \mathrm{CDCl}_{3}\right) \delta: 8.32(\mathrm{~d}, 1 \mathrm{H}$, $J=7.5 \mathrm{~Hz}), 8.00$ (d, $1 \mathrm{H}, J=7.5 \mathrm{~Hz}), 7.90(\mathrm{t}, 1 \mathrm{H}, J=7.5 \mathrm{~Hz}), 7.81(\mathrm{t}, 1 \mathrm{H}, J=$ $7.5 \mathrm{~Hz}), 7.42(\mathrm{t}, 1 \mathrm{H}, J=7.5 \mathrm{~Hz}), 7.26$ (d, $2 \mathrm{H}, J=7.5 \mathrm{~Hz}), 2.40$ (q, $4 \mathrm{H}, J=7.5$ $\mathrm{Hz}$ ), $1.14(\mathrm{t}, 6 \mathrm{H}, J=7.5 \mathrm{~Hz})$; Anal. Calcd for $\mathrm{C}_{19} \mathrm{H}_{17} \mathrm{NO}_{2} \mathrm{~F}_{2}: \mathrm{C}, 69.30 ; \mathrm{H}$, $5.17 ; \mathrm{N}, 4.25$. Found: C, 69.02; H, 5.11; N, 4.46 .

General Procedure for the Synthesis of 3-Substituted 2,4(1H,3H)Quinazolinediones from Amines To a mixture of amine $(1.0 \mathrm{mmol})$ and $\mathrm{Et}_{3} \mathrm{~N}(1.0 \mathrm{mmol})$ in 1,2 -dichloroethane $(10 \mathrm{ml})$ was added triphosgene $(0.40$ $\mathrm{mmol}$ ), and the resulting solution was heated at reflux until the starting amine disappeared (for $c a .2 \mathrm{~h}$ ). Next, methyl anthranilate $(1.0 \mathrm{mmol}$ ) was added, and the resulting mixture was stirred at reflux for $2 \mathrm{~h}$. The solvent was removed under reduced pressure, and to the residue was added EtOH (2 $\mathrm{ml})$ and $2 \mathrm{~N} \mathrm{NaOH}$ solution $(1 \mathrm{ml})$. The resulting solution was then heated in a steam bath until a clear solution was obtained. This solution was cooled, diluted with water, acidified with $2 \mathrm{~N} \mathrm{HCl}(c a .2 \mathrm{ml})$, and extracted with EtOAc. The organic layer was washed with water and brine, dried over $\mathrm{MgSO}_{4}$ and concentrated under reduced pressure. Purification via silica gel column chromatography (eluent: EtOAc/Hex) gave the 3-substituted 2,4(1H,3H)-quinazolinedione.

PAQ-22: (3-(2,6-Diethylphenyl)-2,4(1H,3H)-quinazolinedione) (5) According to the general procedure, $\mathbf{5}$ was obtained in $65 \%$ yield as colorless crystalline cubes after the recrystallization from EtOAc. mp $226{ }^{\circ} \mathrm{C} ;{ }^{1} \mathrm{H}$ NMR $\left(500 \mathrm{MHz}, \mathrm{CDCl}_{3}\right) \delta: 9.19(\mathrm{br} \mathrm{s}, 1 \mathrm{H}), 8.17(\mathrm{~d}, 1 \mathrm{H}, J=8.0 \mathrm{~Hz}), 7.59$ (td, $1 \mathrm{H}, J=8.5,2.0 \mathrm{~Hz}), 7.42(\mathrm{t}, 1 \mathrm{H}, J=8.0 \mathrm{~Hz}), 7.27(\mathrm{~d}, 2 \mathrm{H}, J=8.0 \mathrm{~Hz}), 7.25(\mathrm{t}$, $1 \mathrm{H}, J=8.0 \mathrm{~Hz}), 6.94(\mathrm{~d}, 1 \mathrm{H}, J=8.0 \mathrm{~Hz}), 2.47$ (q, $4 \mathrm{H}, J=8.0 \mathrm{~Hz}), 1.17(\mathrm{t}, 6 \mathrm{H}$, $J=7.5 \mathrm{~Hz}$ ); high reslution (HR)-MS (FAB) Calcd for $\mathrm{C}_{18} \mathrm{H}_{18} \mathrm{~N}_{2} \mathrm{O}_{2}+\mathrm{H}$ : 
295.1447, Found: 295.1463. IR (KBr, cm $\left.{ }^{-1}\right)$ 3200, 1720, 1660; Anal. Calcd for $\mathrm{C}_{18} \mathrm{H}_{18} \mathrm{~N}_{2} \mathrm{O}_{2}$ : C, 73.45; H, 6.16; N, 9.52. Found: C, 73.55; H, 6.41; N, 9.26

$\mathbf{N}$-(2,6-Diethylphenyl)-2-nitrobenzamide (23) To a solution of 2-nitrobenzoyl chloride $(1.71 \mathrm{~g}, 10 \mathrm{mmol})$ and pyridine $(0.5 \mathrm{ml})$ in $\mathrm{CH}_{2} \mathrm{Cl}_{2}(5 \mathrm{ml})$ was added 2,6-diethylaniline (19) $(1.49 \mathrm{~g}, 10 \mathrm{mmol})$. After having been stirred for $30 \mathrm{~min}$ at room temperature, the reaction mixture was poured into water and extracted with $\mathrm{CH}_{2} \mathrm{Cl}_{2}$. The organic layer was washed with water and brine, dried over $\mathrm{Na}_{2} \mathrm{SO}_{4}$, and concentrated under reduced pressure. $\mathrm{Pu}-$ rification via silica gel column chromatography (eluent: EtOAc/Hex: 1/2) gave $N$-(2,6-diethylphenyl)-2-nitrobenzamide (23) (2.51 g, 84\%). Colorless needles from EtOAc/Hex; mp $151-153{ }^{\circ} \mathrm{C} ;{ }^{1} \mathrm{H}-\mathrm{NMR}\left(500 \mathrm{MHz}, \mathrm{CDCl}_{3}\right) \delta$ : $8.11(\mathrm{~d}, 1 \mathrm{H}, J=8.0 \mathrm{~Hz}), 7.76(\mathrm{td}, 1 \mathrm{H}, J=8.0,1.0 \mathrm{~Hz}), 7.73(\mathrm{dd}, 1 \mathrm{H}, J=8.0$, $1.0 \mathrm{~Hz}), 7.65(\mathrm{td}, 1 \mathrm{H}, J=8.0,1.0 \mathrm{~Hz}), 7.29(\mathrm{t}, 1 \mathrm{H}, J=8.0 \mathrm{~Hz}), 7.19(\mathrm{~d}, 2 \mathrm{H}$, $J=8.0 \mathrm{~Hz}$ ), 7.09 (br s, $1 \mathrm{H}), 2.81$ (q, 4H, $J=7.5 \mathrm{~Hz}$ ), 1.29 (t, $6 \mathrm{H}, J=7.5 \mathrm{~Hz}$ ); FAB-MS $m / z$ : $299(\mathrm{M}+\mathrm{H})^{+}$; Anal. Calcd for $\mathrm{C}_{17} \mathrm{H}_{18} \mathrm{~N}_{2} \mathrm{O}_{3}: \mathrm{C}, 68.44 ; \mathrm{H}, 6.08$; N, 9.39. Found: C, 68.35; H, 6.17; N, 9.33

2-Amino- $N$-(2,6-diethylphenyl)benzamide (24) $\quad N$-(2,6-Diethylphenyl)2-nitrobenzamide (23) $(1.98 \mathrm{~g}, 6.65 \mathrm{mmol})$ was dissolved in EtOH (20 ml) and hydrogenated $\left(1 \mathrm{bar} \mathrm{H}_{2}\right.$ ) over $10 \%$ palladium on charcoal. The mixture was filtered through a pad of Celite, and the filtrate was evaporated in vacuo to give 2-amino- $N$-(2,6-diethylphenyl)benzamide (24) (1.86 g, quantitative yield). Colorless needles from EtOAc/Hex; mp $123-124{ }^{\circ} \mathrm{C} ;{ }^{1} \mathrm{H}-\mathrm{NMR}(500$ $\left.\mathrm{MHz} \mathrm{CDCl}_{3}\right) \delta: 7.56(\mathrm{~d}, 1 \mathrm{H}, J=7.5 \mathrm{~Hz}), 7.28(\mathrm{td}, 1 \mathrm{H}, J=7.5,2.0 \mathrm{~Hz}), 7.25$ $(\mathrm{d}, 1 \mathrm{H}, J=7.5 \mathrm{~Hz}), 7.17(\mathrm{~d}, 2 \mathrm{H}, J=7.5 \mathrm{~Hz}), 6.74(\mathrm{~d}, 1 \mathrm{H}, J=7.5 \mathrm{~Hz}), 6.73(\mathrm{t}$, $1 \mathrm{H}, J=7.5 \mathrm{~Hz}$ ), 5.57 (br s, 2H), 2.66 (q, 4H, $J=7.0 \mathrm{~Hz}$ ), 1.22 (t, $6 \mathrm{H}, J=7.0$ $\mathrm{Hz})$; FAB-MS m/z: $269(\mathrm{M}+\mathrm{H})^{+}$; Anal. Calcd for $\mathrm{C}_{17} \mathrm{H}_{20} \mathrm{~N}_{2} \mathrm{O}: \mathrm{C}, 76.09 ; \mathrm{H}$, 7.51; N, 10.44. Found: C, 75.87; H, 7.52; N, 10.27.

General Procedure for Synthesis of $\boldsymbol{N}$-Alkylated PAQ-22 To a solution of $\mathrm{NaH}$ (13 mg, $0.33 \mathrm{mmol})(60 \%$ in mineral oil, washed with Hex) in DMF $(2 \mathrm{ml})$ was added a solution of PAQ-22 (5) $(89 \mathrm{mg}, 0.30 \mathrm{mmol})$ in DMF $(2 \mathrm{ml})$, then the mixture was stirred for $10 \mathrm{~min}$ at room temperature. To the resulting mixture was added alkyl iodide $(0.30 \mathrm{mmol})$, then the mixture was stirred for another $1 \mathrm{~h}$ at room temperature. To the reaction mixture was added water, and the organics were extracted with EtOAc. The extract was washed with water and brine, dried over $\mathrm{Na}_{2} \mathrm{SO}_{4}$, and concentrated under reduced pressure. Purification via silica gel column chromatography (eluent: EtOAc/Hex) gave $N$-alkylated PAQ-22 (22).

PAQ-22M: (1-Methyl-3-(2,6-diethylphenyl)-2,4(1H,3H)-quinazolinedione) (22a) According to the general procedure, 22a was obtained in $81 \%$ yield as colorless crystalline cubes from EtOAc/Hex. mp $126-127^{\circ} \mathrm{C}$; ${ }^{1} \mathrm{H}-\mathrm{NMR}\left(500 \mathrm{MHz}, \mathrm{CDCl}_{3}\right) \delta: 8.28(\mathrm{dd}, 1 \mathrm{H}, J=8.5,2.0 \mathrm{~Hz}), 7.76(\mathrm{td}, 1 \mathrm{H}$, $J=8.5,2.0 \mathrm{~Hz}), 7.37(\mathrm{t}, 1 \mathrm{H}, J=7.5 \mathrm{~Hz}), 7.31(\mathrm{~d}, 1 \mathrm{H}, J=8.5 \mathrm{~Hz}), 7.30(\mathrm{~d}, 1 \mathrm{H}$, $J=8.0 \mathrm{~Hz}), 7.24(\mathrm{~d}, 2 \mathrm{H}, J=7.5 \mathrm{~Hz}), 3.67$ (s, 3H), 2.42 (q, 4H, $J=8.0 \mathrm{~Hz})$, $1.15(\mathrm{t}, 6 \mathrm{H}, J=8.0 \mathrm{~Hz})$; FAB-MS $m / z: 309(\mathrm{M}+\mathrm{H})^{+}$; HR-MS (FAB) Calcd for $\mathrm{C}_{19} \mathrm{H}_{20} \mathrm{~N}_{2} \mathrm{O}_{2}+\mathrm{H}$ : 309.1603, Found: 309.1597; Anal. Calcd for $\mathrm{C}_{19} \mathrm{H}_{20} \mathrm{~N}_{2} \mathrm{O}_{2}$ : C, 74.00; H, 6.54; N, 9.08. Found: C, 74.06; H, 6.66; N, 9.07.

PAQ-22E: (1-Ethyl-3-(2,6-diethylphenyl)-2,4(1 H,3H)-quinazolinedione) (22b) According to the general procedure, 22b was obtained quantitatively as colorless needles, which were recrystallized from EtOAc; mp $123-124{ }^{\circ} \mathrm{C} ;{ }^{1} \mathrm{H}-\mathrm{NMR}\left(500 \mathrm{MHz}, \mathrm{CDCl}_{3}\right) \delta: 8.29(\mathrm{dd}, 1 \mathrm{H}, J=8.0,2.0 \mathrm{~Hz})$, $7.74(\mathrm{td}, 1 \mathrm{H}, J=8.0,2.0 \mathrm{~Hz}), 7.36(\mathrm{t}, 1 \mathrm{H}, J=8.0 \mathrm{~Hz}), 7.31(\mathrm{~d}, 1 \mathrm{H}, J=8.0 \mathrm{~Hz})$, $7.29(\mathrm{t}, 1 \mathrm{H}, J=8.0 \mathrm{~Hz}), 7.23(\mathrm{~d}, 2 \mathrm{H}, J=8.0 \mathrm{~Hz}), 4.25(\mathrm{q}, 2 \mathrm{H}, J=7.5 \mathrm{~Hz}), 2.41$ (q, $4 \mathrm{H}, J=7.5 \mathrm{~Hz}), 1.38$ (t, 3H, $J=7.5 \mathrm{~Hz}), 1.15$ (t, 6H, $J=7.5 \mathrm{~Hz})$; FAB-MS $m / z: 323(\mathrm{M}+\mathrm{H})^{+}$; Anal. Calcd for $\mathrm{C}_{20} \mathrm{H}_{22} \mathrm{~N}_{2} \mathrm{O}_{2}$ : C, 74.51; H, 6.88; N, 8.69. Found: C, 74.80; H, 7.03; N, 8.75.

PAQ-22P: (1-Propyl-3-(2,6-diethylphenyl)-2,4(1 H,3H)-quinazolinedione) (22c) According to the general procedure, 22c was obtained in $70 \%$ yield as colorless needles, which were recrystallized from EtOAc/n-pentane; mp $131.5-132{ }^{\circ} \mathrm{C} ;{ }^{1} \mathrm{H}-\mathrm{NMR}\left(500 \mathrm{MHz}, \mathrm{CDCl}_{3}\right) \delta: 8.29(\mathrm{~d}, 1 \mathrm{H}, J=8.0 \mathrm{~Hz})$, $7.73(\mathrm{t}, 1 \mathrm{H}, J=8.0 \mathrm{~Hz}), 7.36(\mathrm{t}, 1 \mathrm{H}, J=8.0 \mathrm{~Hz}), 7.28(\mathrm{~d}, 1 \mathrm{H}, J=8.0 \mathrm{~Hz}), 7.28$ $(\mathrm{t}, 1 \mathrm{H}, J=8.0 \mathrm{~Hz}), 7.23(\mathrm{~d}, 2 \mathrm{H}, J=8.0 \mathrm{~Hz}), 4.16(\mathrm{q}, 2 \mathrm{H}, J=8.0 \mathrm{~Hz}), 2.41(\mathrm{q}$, $4 \mathrm{H}, J=8.0 \mathrm{~Hz}), 1.82(\mathrm{qt}, 2 \mathrm{H}, J=8.0,8.0 \mathrm{~Hz}), 1.15(\mathrm{t}, 6 \mathrm{H}, J=8.0 \mathrm{~Hz}), 1.03(\mathrm{t}$, $3 \mathrm{H}, J=8.0 \mathrm{~Hz})$; FAB-MS $m / z: 337(\mathrm{M}+\mathrm{H})^{+}$; Anal. Calcd for $\mathrm{C}_{21} \mathrm{H}_{24} \mathrm{~N}_{2} \mathrm{O}_{2}$ : C, 74.97; H, 7.19; N, 8.33. Found: C, 75.01; H, 7.20; N, 8.33.

PAQ-22B: (1-Butyl-3-(2,6-diethylphenyl)-2,4(1H,3H)-quinazolinedione) (22d) According to the general procedure, 22d was obtained in $95 \%$ yield as colorless needles, which were recrystallized from $\mathrm{EtOH} / n$-pentane; mp $84.5-85^{\circ} \mathrm{C} ;{ }^{1} \mathrm{H}-\mathrm{NMR}\left(500 \mathrm{MHz}, \mathrm{CDCl}_{3}\right) \delta: 8.29$ (dd, $1 \mathrm{H}, J=8.0$, $2.0 \mathrm{~Hz}), 7.74(\mathrm{td}, 1 \mathrm{H}, J=8.0,2.0 \mathrm{~Hz}), 7.36(\mathrm{t}, 1 \mathrm{H}, J=8.0 \mathrm{~Hz}), 7.29(\mathrm{~d}, 1 \mathrm{H}$, $J=8.0 \mathrm{~Hz}), 7.28(\mathrm{t}, 1 \mathrm{H}, J=8.0 \mathrm{~Hz}), 7.23(\mathrm{~d}, 2 \mathrm{H}, J=8.0 \mathrm{~Hz}), 4.19(\mathrm{t}, 2 \mathrm{H}$, $J=8.0 \mathrm{~Hz}$ ), 2.41 (q, 4H, $J=7.5 \mathrm{~Hz}), 1.76(\mathrm{tt}, 2 \mathrm{H}, J=7.5,7.5 \mathrm{~Hz}), 1.46(\mathrm{qt}$, $2 \mathrm{H}, J=7.5,7.5 \mathrm{~Hz}), 1.15(\mathrm{t}, 6 \mathrm{H}, J=7.5 \mathrm{~Hz}), 0.99$ (t, $3 \mathrm{H}, J=7.5 \mathrm{~Hz}$ ); FABMS $m / z: 351(\mathrm{M}+\mathrm{H})^{+}$; Anal. Calcd for $\mathrm{C}_{22} \mathrm{H}_{26} \mathrm{~N}_{2} \mathrm{O}_{2}: \mathrm{C}, 75.40 ; \mathrm{H}, 7.48 ; \mathrm{N}$,
7.99. Found: C, 75.28; H, 7.50; N, 8.00.

PAQ-22Bn: (1-Benzyl-3-(2,6-diethylphenyl)-2,4(1H,3H)-quinazolinedione) (22e) To a solution of $\mathrm{NaH}(7.0 \mathrm{mg}, 0.17 \mathrm{mmol}(60 \%$ in mineral oil, washed with Hex)) in DMF (1 ml) was added a solution of PAQ-22 (5) (45 mg, $0.15 \mathrm{mmol})$ in DMF $(1 \mathrm{ml})$, and the mixture was stirred at room temperature for $10 \mathrm{~min}$. To the resulting mixture was added benzyl bromide (29 $\mathrm{mg}, 0.17 \mathrm{mmol}$ ), and the whole was stirred for $1 \mathrm{~h}$. Water was added, and organics were extracted with EtOAc. The extract was washed with brine, dried over $\mathrm{Na}_{2} \mathrm{SO}_{4}$ and concentrated under reduced pressure. The residue was purified by silica gel column chromatography (eluent: EtOAc/Hex: 1/10-1/4) to give PAQ-22Bn (22e) (38 mg, 65\%) as colorless cubes, which were recrystallized from MeOH; mp $188-190{ }^{\circ} \mathrm{C} ;{ }^{1} \mathrm{H}-\mathrm{NMR}\left(500 \mathrm{MHz}, \mathrm{CDCl}_{3}\right) \delta$ : $8.28(\mathrm{dd}, 1 \mathrm{H}, J=8.0,1.0 \mathrm{~Hz}), 7.61(\mathrm{td}, 1 \mathrm{H}, J=8.0,1.0 \mathrm{~Hz}), 7.38(\mathrm{t}, 1 \mathrm{H}$, $J=8.0 \mathrm{~Hz}), 7.35(\mathrm{t}, 1 \mathrm{H}, J=8.0 \mathrm{~Hz}), 7.31(\mathrm{~d}, 2 \mathrm{H}, J=8.0 \mathrm{~Hz}), 7.27(\mathrm{t}, 1 \mathrm{H}$, $J=8.0 \mathrm{~Hz}), 7.26(\mathrm{t}, 1 \mathrm{H}, J=8.0 \mathrm{~Hz}), 7.25(\mathrm{~d}, 2 \mathrm{H}, J=8.0 \mathrm{~Hz}), 7.22(\mathrm{~d}, 2 \mathrm{H}$, $J=8.0 \mathrm{~Hz}$ ), 5.43 (br s, 2H), 2.48 (q, $4 \mathrm{H}, J=8.0 \mathrm{~Hz}), 1.18(\mathrm{t}, 6 \mathrm{H}, J=8.0 \mathrm{~Hz})$; FAB-MS m/z: $385(\mathrm{M}+\mathrm{H})^{+}$; Anal. Calcd for $\mathrm{C}_{25} \mathrm{H}_{24} \mathrm{~N}_{2} \mathrm{O}_{2}: \mathrm{C}, 78.10 ; \mathrm{H}, 6.29$; N, 7.29. Found: C, 78.11; H, 6.47; N, 7.29.

PAZOX-22: $\quad \boldsymbol{N}$-(2,6-Diethylphenyl)-3,1-benzoxazin-4-one (6) To a mixture of 2,6-diethylaniline (19) (149 mg, $1.0 \mathrm{mmol})$ and $\mathrm{Et}_{3} \mathrm{~N}(100 \mathrm{mg}, 1.0$ $\mathrm{mmol})$ in 1,2-dichloroethane $(10 \mathrm{ml})$ was added triphosgene $(119 \mathrm{mg}, 0.40$ $\mathrm{mmol}$ ), and the mixture was heated at reflux until the amine was consumed (for $c a .2 \mathrm{~h}$ ). The reaction mixture was concentrated in vacuo, and to the residue was added a solution of anthranilic acid $(137 \mathrm{mg}, 1.0 \mathrm{mmol})$ in THF $(1 \mathrm{ml})$. This mixture was stirred at $60^{\circ} \mathrm{C}$ for $20 \mathrm{~h}$, then diluted with water, and the organics were extracted with EtOAc. The extract was washed with water and brine, dried over $\mathrm{MgSO}_{4}$ and concentrated under reduced pressure to give 2-[3-(2,6-diethylphenylureido)]benzoic acid (21b). The acid 21b was dissolved in conc. $\mathrm{H}_{2} \mathrm{SO}_{4}(3 \mathrm{ml})$, and the mixture was stirred at room temperature for $1.5 \mathrm{~h}$. To the reaction mixture was added ice-cold water, and after neutralization with $2 \mathrm{~N} \mathrm{NaOH}$, the organics were extracted with $\mathrm{CH}_{2} \mathrm{Cl}_{2}$. The organic solution was dried over $\mathrm{MgSO}_{4}$ and concentrated under reduced pressure, and the residue was purified by recrystallization from $\mathrm{CH}_{2} \mathrm{Cl}_{2} / \mathrm{Hex}$ to give $6(119 \mathrm{mg}, 40 \%)$ as a white powder; $\mathrm{mp} 185-187^{\circ} \mathrm{C}$; ${ }^{1} \mathrm{H}-\mathrm{NMR}\left(500 \mathrm{MHz}, \mathrm{CDCl}_{3}\right) \delta: 8.06(\mathrm{dd}, 1 \mathrm{H}, J=8.5,1.5 \mathrm{~Hz}), 7.61(\mathrm{t}, 1 \mathrm{H}$, $J=8.0 \mathrm{~Hz}), 7.31(\mathrm{t}, 1 \mathrm{H}, J=8.0 \mathrm{~Hz}), 7.22(\mathrm{td}, 1 \mathrm{H}, J=8.0,1.5 \mathrm{~Hz}), 7.20(\mathrm{~d}, 1 \mathrm{H}$, $J=7.5 \mathrm{~Hz}), 7.19(\mathrm{~d}, 2 \mathrm{H}, J=8.0 \mathrm{~Hz}), 2.67(\mathrm{q}, 4 \mathrm{H}, J=7.5 \mathrm{~Hz}), 1.22(\mathrm{t}, 6 \mathrm{H}$, $J=8.0 \mathrm{~Hz}$ ); HR-MS (FAB) Calcd for $\mathrm{C}_{18} \mathrm{H}_{18} \mathrm{~N}_{2} \mathrm{O}_{2}+\mathrm{H}$ 295.1447; Found 295.1461; IR (KBr, cm ${ }^{-1}$ ) 3000, 1780, 1670. Anal. Calcd for $\mathrm{C}_{18} \mathrm{H}_{18} \mathrm{~N}_{2} \mathrm{O}_{2}$ : C, 73.45; H, 6.16; N, 9.52, Found: C, 73.15; H, 6.15; N, 9.37.

$\mathbf{N}$-(2,6-Diethylphenyl)-2-hydroxybenzamide (25) A solution of 2,6-diethylaniline (19) $(1.49 \mathrm{~g}, 10 \mathrm{mmol})$ and salicylic acid $(1.38 \mathrm{~g}, 10 \mathrm{mmol})$ in xylene $(20 \mathrm{ml})$ was treated with $\mathrm{PCl}_{3}(0.87 \mathrm{ml}, 10 \mathrm{mmol})$ at room temperature, and the mixture was heated to reflux for $3 \mathrm{~h}$. The reaction mixture was cooled, and water was added. The organics were extracted with EtOAc, and the extract was washed with water and brine, dried over $\mathrm{Na}_{2} \mathrm{SO}_{4}$, and concentrated under reduced pressure. The residue was purified by silica gel column chromatography (eluent: EtOAc/Hex: 1/4) to give $N$-(2,6-diethylphenyl)-2-hydroxybenzamide (25) $(2.31 \mathrm{~g}, 86 \%)$, as colorless crystalline cubes from diisopropyl ether; ${ }^{1} \mathrm{H}-\mathrm{NMR}\left(500 \mathrm{MHz}, \mathrm{CDCl}_{3}\right) \delta: 12.16$ (s, 1H), 7.59 (dd, $1 \mathrm{H}, J=7.5,1.0 \mathrm{~Hz}), 7.51$ (br s, $1 \mathrm{H}), 7.48$ (td, $1 \mathrm{H}, J=7.5$, $1.0 \mathrm{~Hz}), 7.30$ (t, $1 \mathrm{H}, J=7.5 \mathrm{~Hz}), 7.19(\mathrm{~d}, 2 \mathrm{H}, J=7.5 \mathrm{~Hz}), 7.06(\mathrm{~d}, 1 \mathrm{H}, J=7.5$ $\mathrm{Hz}), 6.95(\mathrm{t}, 1 \mathrm{H}, J=7.5 \mathrm{~Hz}), 2.65(\mathrm{q}, 4 \mathrm{H}, J=7.5 \mathrm{~Hz}), 1.21(\mathrm{t}, 6 \mathrm{H}, J=7.5 \mathrm{~Hz})$; FAB-MS $m / z$ : $270(\mathrm{M}+\mathrm{H})^{+}$; Anal. Calcd for $\mathrm{C}_{17} \mathrm{H}_{19} \mathrm{NO}$ : C, 75.81; H, 7.11; N, 5.20. Found: C, 75.73; H, 7.10; N, 5.05.

POQ-22: 3-(2,6-Diisopropylphenyl)-2H-1,3-benzoxazine-2,4(3H)quinazolinedione (26) A solution of $N$-(2,6-diethylphenyl)-2-hydroxybenzamide (25) $(135 \mathrm{mg}, 0.5 \mathrm{mmol})$ in pyridine $(2 \mathrm{ml})$ at $0{ }^{\circ} \mathrm{C}$ was treated with ethyl chloroformate $(109 \mathrm{mg}, 1.0 \mathrm{mmol})$, allowed to warm to room temperature, then the mixture was heated to reflux for $2 \mathrm{~h}$. To the reaction mixture was added water, and after neutralization with $2 \mathrm{~N} \mathrm{HCl}$, the organics were extracted with EtOAc. The extract was washed with water and brine, dried over $\mathrm{Na}_{2} \mathrm{SO}_{4}$, and concentrated under reduced pressure. Purification by silica gel column chromatography (eluent: EtOAc/Hex: 1/10 - 1/4) gave POQ-22 (26) $(57 \mathrm{mg}, 37 \%)$ as colorless needles from $\mathrm{EtOH} / \mathrm{Hex}$; mp $119-120^{\circ} \mathrm{C}$; ${ }^{1} \mathrm{H}-\mathrm{NMR}\left(500 \mathrm{MHz}, \mathrm{CDCl}_{3}\right) \delta: 8.14(\mathrm{dd}, 1 \mathrm{H}, J=8.0,1.5 \mathrm{~Hz}), 7.77(\mathrm{td}, 1 \mathrm{H}$, $J=8.0,1.5 \mathrm{~Hz}), 7.42(\mathrm{t}, 1 \mathrm{H}, J=8.0 \mathrm{~Hz}), 7.41(\mathrm{t}, 1 \mathrm{H}, J=8.0 \mathrm{~Hz}), 7.38(\mathrm{~d}, 1 \mathrm{H}$, $J=8.0 \mathrm{~Hz}), 7.26(\mathrm{~d}, 2 \mathrm{H}, J=8.0 \mathrm{~Hz}), 2.47(\mathrm{q}, 2 \mathrm{H}, J=8.0 \mathrm{~Hz}), 2.46(\mathrm{q}, 2 \mathrm{H}$, $J=8.0 \mathrm{~Hz}), 1.18(\mathrm{t}, 6 \mathrm{H}, J=8.0 \mathrm{~Hz})$; FAB-MS $m / z: 296(\mathrm{M}+\mathrm{H})^{+}$; Anal. Calcd for $\mathrm{C}_{18} \mathrm{H}_{17} \mathrm{NO}_{3}$ : C, 73.20; H, 5.80; N, 4.74. Found: C, 73.07; H, 5.86; N, 4.73 .

3-(2,6-Diethylphenyl)-2-thio-2,4(1H,3H)-quinazolinedione (27) A mixture of carbon disulfide $(0.4 \mathrm{ml}, 6.74 \mathrm{mmol})$, DBU $(0.05 \mathrm{ml}, 0.337 \mathrm{mmol})$ and 2-amino- $N$-(2,6-diethylphenyl)benzamide (24) $(90 \mathrm{mg}, 0.337 \mathrm{mmol})$ in 
DMF $(1 \mathrm{ml})$ was heated at $50^{\circ} \mathrm{C}$ for $3 \mathrm{~h}$ under argon. To the reaction mixture was added water, and the organics were extracted with EtOAc. The extract was washed with brine, dried over $\mathrm{MgSO}_{4}$, filtered and concentrated in vacuo. The residue was purified by silica gel column chromatography (eluent: EtOAc/Hex: 1/4) to give $27(81 \mathrm{mg}, 78 \%)$ as colorless plates from EtOAc/Hex; mp $248-254{ }^{\circ} \mathrm{C} ;{ }^{1} \mathrm{H}-\mathrm{NMR}\left(500 \mathrm{MHz}, \mathrm{CDCl}_{3}\right) \delta: 11.45(\mathrm{brs}$, $1 \mathrm{H}), 8.19(\mathrm{~d}, 1 \mathrm{H}, J=8.0 \mathrm{~Hz}), 7.64(\mathrm{t}, 1 \mathrm{H}, J=8.0 \mathrm{~Hz}), 7.46(\mathrm{t}, 1 \mathrm{H}, J=8.0 \mathrm{~Hz})$, $7.33(\mathrm{t}, 1 \mathrm{H}, J=7.5 \mathrm{~Hz}), 7.30(\mathrm{~d}, 2 \mathrm{H}, J=7.5 \mathrm{~Hz}), 7.22(\mathrm{~d}, 1 \mathrm{H}, J=8.0 \mathrm{~Hz})$, $2.56-2.39(\mathrm{~m}, 4 \mathrm{H}), 1.21(\mathrm{t}, 6 \mathrm{H}, J=7.5 \mathrm{~Hz})$; FAB-MS $m / z: 311(\mathrm{M}+\mathrm{H})^{+}$; Anal. Calcd for $\mathrm{C}_{18} \mathrm{H}_{18} \mathrm{~N}_{2} \mathrm{OS}$ : C, 69.65; H, 5.84; N, 9.02. Found: C, 69.76; H, 5.99; N, 8.96.

3-(2,6-Diethylphenyl)-2,3-dihydro-4(1H)-quinazolinone (28) To a solution of 2-amino- $N$-(2,6-diethylphenyl)benzamide (24) (135 mg, 0.50 $\mathrm{mmol})$ and $\mathrm{NaOH}(20 \mathrm{mg}, 0.50 \mathrm{mmol})$ in $\mathrm{EtOH}(5 \mathrm{ml})$ was added formalin $(37 \%, 1 \mathrm{ml})$, then the mixture was stirred for $30 \mathrm{~min}$ at $60^{\circ} \mathrm{C}$. The reaction mixture was cooled and diluted with water, and the organics were extracted with EtOAc. The extract was washed with water and brine and concentrated under reduced pressure. Purification by silica gel column chromatography (eluent: EtOAc/Hex: 1/2) gave $28(127 \mathrm{mg}, 90 \%)$ as colorless needles from EtOAc/Hex; mp 182-184 ${ }^{\circ} \mathrm{C} ;{ }^{1} \mathrm{H}-\mathrm{NMR}\left(500 \mathrm{MHz}, \mathrm{CDCl}_{3}\right) \delta: 7.98(\mathrm{~d}, 1 \mathrm{H}$, $J=7.5 \mathrm{~Hz}), 7.31(\mathrm{td}, 1 \mathrm{H}, J=7.5,1.0 \mathrm{~Hz}), 7.24(\mathrm{t}, 1 \mathrm{H}, J=7.5 \mathrm{~Hz}), 7.16(\mathrm{~d}, 2 \mathrm{H}$, $J=7.5 \mathrm{~Hz}), 6.89(\mathrm{t}, 1 \mathrm{H}, J=7.5 \mathrm{~Hz}), 6.70(\mathrm{~d}, 1 \mathrm{H}, J=7.5 \mathrm{~Hz}), 4.68(\mathrm{~s}, 2 \mathrm{H})$, $2.72-2.57(\mathrm{~m}, 4 \mathrm{H}), 1.19(\mathrm{t}, 6 \mathrm{H}, J=7.5 \mathrm{~Hz})$; FAB-MS $m / z: 281(\mathrm{M}+\mathrm{H})^{+}$; Anal. Calcd for $\mathrm{C}_{18} \mathrm{H}_{20} \mathrm{~N}_{2} \mathrm{O}: \mathrm{C}, 77.11 ; \mathrm{H}, 7.19 ; \mathrm{N}, 9.99$ Found: C, 77.09; H, $7.28 ; \mathrm{N}, 9.93$.

3-(2,6-Diethylphenyl)-4-thio-2,4(1H,3H)-quinazolinedione (29) A solution of PAQ-22 (5) $(295 \mathrm{mg}, 1.0 \mathrm{mmol})$ and $\mathrm{P}_{4} \mathrm{~S}_{10}(267 \mathrm{mg}, 0.60 \mathrm{mmol})$ in xylene $(10 \mathrm{ml})$ was stirred at $130^{\circ} \mathrm{C}$ for $10 \mathrm{~h}$, then concentrated in vacuo, and the residue was purified by silica gel column chromatography (eluent: EtOAc/Hex: 1/4) to give $\mathbf{2 9}(274 \mathrm{mg}, \mathbf{8 8 \%})$ as orange needles from EtOAc/Hex; mp $189^{\circ} \mathrm{C}$; ${ }^{1} \mathrm{H}-\mathrm{NMR}\left(500 \mathrm{MHz}, \mathrm{CDCl}_{3}\right) \delta: 10.10$ (brs, $\left.1 \mathrm{H}\right)$, $8.56(\mathrm{~d}, 1 \mathrm{H}, J=8.0 \mathrm{~Hz}), 7.51(\mathrm{td}, 1 \mathrm{H}, J=8.0,1.0 \mathrm{~Hz}), 7.44(\mathrm{t}, 1 \mathrm{H}, J=7.5 \mathrm{~Hz})$, $7.31(\mathrm{~d}, 2 \mathrm{H}, J=7.5 \mathrm{~Hz}), 7.20(\mathrm{td}, 1 \mathrm{H}, J=8.0,1.0 \mathrm{~Hz}), 6.73(\mathrm{~d}, 1 \mathrm{H}, J=8.0$ $\mathrm{Hz}), 2.44(\mathrm{q}, 4 \mathrm{H}, J=7.5 \mathrm{~Hz}), 1.19(\mathrm{t}, 6 \mathrm{H}, J=7.5 \mathrm{~Hz})$; FAB-MS $m / z: 311$ $(\mathrm{M}+\mathrm{H})^{+}$; Anal. Calcd for $\mathrm{C}_{18} \mathrm{H}_{18} \mathrm{~N}_{2} \mathrm{OS}$ : C, 69.65; H, 5.84; N, 9.02. Found: C, 69.44; H, 6.06; N, 8.62.

2-Amino- $\boldsymbol{N}$-(2,6-diethylphenyl)benzenemethanamine (32) To a mixture of 2,6-diethylaniline $(0.82 \mathrm{~g}, 5.5 \mathrm{mmol})$ and $\mathrm{K}_{2} \mathrm{CO}_{3}(0.83 \mathrm{~g}, 6.0 \mathrm{mmol})$ in DMF (5 ml) was added 2-nitrobenzyl bromide (31) $(1.08 \mathrm{~g}, 5.0 \mathrm{mmol})$, and the mixture was stirred at $60^{\circ} \mathrm{C}$ for $6 \mathrm{~h}$. The reaction mixture was diluted with water and extracted with EtOAc. The extract was washed with water and brine, and concentrated under reduced pressure. Purification by silica gel column chromatography (eluent: EtOAc/Hex: 1/10) gave $N-2,6-$ diethylphenyl-2-nitrobenzylamine $(1.02 \mathrm{~g}, 72 \%$ ). A mixture of $\mathrm{N}-2,6-\mathrm{di}-$ ethylphenyl-2-nitrobenzylamine (143 mg, $0.50 \mathrm{~mol})$, iron(III) oxide hydroxide $(100 \mathrm{mg})$, and $\mathrm{MeOH}(85 \mathrm{ml})$ was stirred at $60^{\circ} \mathrm{C}$ for $10 \mathrm{~min}$. To the resulting mixture was added hydrazine hydrate $(100 \%, 0.1 \mathrm{ml})$, dropwise, then the mixture was stirred at $60{ }^{\circ} \mathrm{C}$ for another $4 \mathrm{~h}$. The reaction mixture was cooled to room temperature, diluted with EtOAc, filtered, and concentrated. Purification via silica gel column chromatography (eluent: EtOAc/Hex: 1/8-1/4) gave 2-amino- $N$-(2,6-diethylphenyl)benzenemethanamine (32) $(125 \mathrm{mg}, 98 \%)$ as a yellow oil. ${ }^{1} \mathrm{H}-\mathrm{NMR}\left(500 \mathrm{MHz}, \mathrm{CDCl}_{3}\right) \delta: 7.14(\mathrm{td}, 1 \mathrm{H}$, $J=8.0,1.0 \mathrm{~Hz}), 7.12(\mathrm{dd}, 1 \mathrm{H}, J=8.0,1.0 \mathrm{~Hz}), 7.10(\mathrm{~s}, 1 \mathrm{H}), 7.08(\mathrm{~s}, 2 \mathrm{H}), 7.03$ $(\mathrm{d}, 1 \mathrm{H}, J=8.0 \mathrm{~Hz}), 7.02(\mathrm{td}, 1 \mathrm{H}, J=8.0,1.0 \mathrm{~Hz}), 6.74(\mathrm{td}, 1 \mathrm{H}, J=8.0,1.0$ $\mathrm{Hz}), 6.73(\mathrm{~d}, 2 \mathrm{H}, J=8.0 \mathrm{~Hz}), 4.02(\mathrm{~s}, 2 \mathrm{H}), 2.73(\mathrm{q}, 4 \mathrm{H}, J=7.5 \mathrm{~Hz}), 1.26(\mathrm{t}$, $6 \mathrm{H}, J=7.5 \mathrm{~Hz})$.

3-(2,6-Diethylphenyl)-3,4-dihydro-2(1H)-quinazolinone (30) To a solution of 2-amino- $N$-(2,6-diethylphenyl)benzenemethanamine (32) (55 mg, $0.21 \mathrm{mmol})$ and triethylamine $(0.03 \mathrm{ml}, 0.21 \mathrm{mmol})$ in 1,2 -dichloroethane $(2$ $\mathrm{ml}$ ) was added triphosgene $(24 \mathrm{mg}, 0.08 \mathrm{mmol})$, and the resulting mixture was heated at reflux for $2 \mathrm{~h}$. To the resulting mixture was added methyl anthranilate $(1.0 \mathrm{mmol})$, and stirring was continued at reflux for another $2 \mathrm{~h}$. The reaction mixture was concentrated in vacuo, and the residue was purified by silica gel column chromatography (eluent: EtOAc/Hex: 1/4) to give 30 (48 mg, 83\%) as colorless cubes from EtOAc/Hex; mp $191{ }^{\circ} \mathrm{C}$; ${ }^{1} \mathrm{H}-\mathrm{NMR}$ $\left(500 \mathrm{MHz} \mathrm{CDCl}_{3}\right) \delta: 7.57(\mathrm{brs}, 1 \mathrm{H}), 7.29(\mathrm{t}, 1 \mathrm{H}, J=8.0 \mathrm{~Hz}), 7.20(\mathrm{~d}, 2 \mathrm{H}$, $J=8.0 \mathrm{~Hz}), 7.18(\mathrm{t}, 1 \mathrm{H}, J=8.0 \mathrm{~Hz}), 7.02(\mathrm{~d}, 1 \mathrm{H}, J=8.0 \mathrm{~Hz}), 6.95(\mathrm{t}, 1 \mathrm{H}$, $J=8.0 \mathrm{~Hz}), 6.71(\mathrm{~d}, 1 \mathrm{H}, J=8.0 \mathrm{~Hz}), 4.62(\mathrm{~s}, 2 \mathrm{H}), 2.73-2.55(\mathrm{~m}, 4 \mathrm{H}), 1.23$ $(\mathrm{t}, 6 \mathrm{H}, J=7.5 \mathrm{~Hz})$; FAB-MS $m / z$ : $281(\mathrm{M}+\mathrm{H})^{+}$; Anal. Calcd for $\mathrm{C}_{18} \mathrm{H}_{20} \mathrm{~N}_{2} \mathrm{O}$ : C, 77.11; H, 7.19; N, 9.99 Found: C, 77.13; H, 7.30; N, 9.95.

General Procedure for the Synthesis of Nitro-Substituted PAQ-22 from Nitroanthranilic Acid A mixture of nitro-substituted anthranilic acid (33) (910 mg, $5 \mathrm{mmol})$, 2,6-diethylaniline (19) (750 mg, $5 \mathrm{mmol})$, HOBt (740 mg, $5.5 \mathrm{mmol})$ and EDC (1.15 g, 6 mmol) in DMF (5 ml) was stirred for
$20 \mathrm{~h}$. The reaction mixture was concentrated in vacuo, and the residue was purified by silica gel column chromatography (eluent: EtOAc/Hex: 1/4) to give 34. A mixture of the amide compound $34(627 \mathrm{mg}, 2.0 \mathrm{mmol})$, $\mathrm{Et}_{3} \mathrm{~N}(223 \mathrm{mg}, 2.2 \mathrm{mmol})$ and triphosgene $(237 \mathrm{mg}, 0.80 \mathrm{mmol})$ in $1,2-$ dichloroethane $(20 \mathrm{ml})$ was heated at reflux for $30 \mathrm{~min}$. The reaction mixture was cooled, and the organics were extracted with EtOAc. The extract was washed with water and brine, dried over $\mathrm{MgSO}_{4}$ and concentrated under reduced pressure. The residue was purified by silica gel column chromatography (eluent: EtOAc/Hex) to give the nitro-substituted PAQ-22 (35).

6-Nitro-3-(2,6-diethylphenyl)-2,4(1 H,3H)-quinazolinedione (35a) According to the general procedure, 35a was obtained in $32 \%$ yield ( 2 steps) as pale yellow plates from EtOAc/Hex; mp $268-272{ }^{\circ} \mathrm{C}$; ${ }^{1} \mathrm{H}-\mathrm{NMR}(500$ $\left.\mathrm{MHz}, \mathrm{CDCl}_{3}\right) \delta: 10.25$ (br s, $\left.1 \mathrm{H}\right), 9.01(\mathrm{~d}, 1 \mathrm{H}, J=2.5 \mathrm{~Hz}), 8.26(\mathrm{dd}, 1 \mathrm{H}$, $J=9.0,2.5 \mathrm{~Hz}), 7.56(\mathrm{t}, 1 \mathrm{H}, J=7.5 \mathrm{~Hz}), 7.36(\mathrm{~d}, 2 \mathrm{H}, J=7.5 \mathrm{~Hz}), 6.68(\mathrm{~d}, 1 \mathrm{H}$, $J=9.0 \mathrm{~Hz}), 2.46(\mathrm{q}, 4 \mathrm{H}, J=8.0 \mathrm{~Hz}), 1.17(\mathrm{t}, 6 \mathrm{H}, J=8.0 \mathrm{~Hz})$; FAB-MS $m / z$ : $340(\mathrm{M}+\mathrm{H})^{+}$; Anal. Calcd for $\mathrm{C}_{18} \mathrm{H}_{17} \mathrm{~N}_{3} \mathrm{O}_{4}: \mathrm{C}, 63.71 ; \mathrm{H}, 5.05 ; \mathrm{N}, 12.38: \mathrm{C}$, $63.57, \mathrm{H}, 5.18 ; \mathrm{N}, 12.18$.

7-Nitro-3-(2,6-diethylphenyl)-2,4(1H,3H)-quinazolinedione (35b) According to the general procedure, $\mathbf{3 5}$ b was obtained in $65 \%$ yield ( 2 steps) as yellow needles from EtOAc/Hex; mp 204-209 ${ }^{\circ} \mathrm{C} ;{ }^{1} \mathrm{H}-\mathrm{NMR}(500 \mathrm{MHz}$, $\left.\mathrm{CDCl}_{3}\right) \delta: 9.73(\mathrm{br} \mathrm{s}, 1 \mathrm{H}), 8.36(\mathrm{~d}, 1 \mathrm{H}, J=8.5 \mathrm{~Hz}), 8.04(\mathrm{dd}, 1 \mathrm{H}, J=8.5,2.5$ $\mathrm{Hz}), 7.87(\mathrm{~d}, 1 \mathrm{H}, J=2.0 \mathrm{~Hz}), 7.43(\mathrm{t}, 1 \mathrm{H}, J=8.0 \mathrm{~Hz}), 7.27$ (d, $2 \mathrm{H}, J=8.0 \mathrm{~Hz})$, $2.45(\mathrm{q}, 4 \mathrm{H}, J=7.5 \mathrm{~Hz}), 1.18(\mathrm{t}, 6 \mathrm{H}, J=7.5 \mathrm{~Hz})$; FAB-MS $m / z: 340$ $(\mathrm{M}+\mathrm{H})^{+}$; Anal. Calcd for $\mathrm{C}_{18} \mathrm{H}_{17} \mathrm{~N}_{3} \mathrm{O}_{4}: \mathrm{C}, 63.71 ; \mathrm{H}, 5.05 ; \mathrm{N}, 12.38: \mathrm{C}$, 63.56, H, 5.16; N, 12.24 .

8-Nitro-3-(2,6-diethylphenyl)-2,4(1H,3H)-quinazolinedione (35c) To a mixture of $37(1.25 \mathrm{~g}, 5.55 \mathrm{mmol})$ and $\mathrm{Et}_{3} \mathrm{~N}(1.55 \mathrm{ml}, 11.11 \mathrm{mmol})$ in THF $(15 \mathrm{ml})$ was added ethyl chloroformate $(0.8 \mathrm{ml}, 8.33 \mathrm{mmol})$, dropwise, at $-10^{\circ} \mathrm{C}$, and the resulting mixture was stirred for $1 \mathrm{~h}$. TLC analysis showed complete conversion to a very non-polar material. To the mixture was added dropwise a solution of $\mathrm{NaN}_{3}(0.9 \mathrm{~g}, 13.87 \mathrm{mmol})$ in water $(5.4 \mathrm{ml})$, and the mixture was stirred for another $1 \mathrm{~h}$. The reaction mixture was diluted with water and extracted with toluene $(30 \mathrm{ml})$. The combined organic extract was washed with brine, dried over $\mathrm{Na}_{2} \mathrm{SO}_{4}$, filtered, and concentrated to $\mathrm{ca}$. half volume in vacuo. The toluene solution was then slowly brought to reflux. After $1.5 \mathrm{~h}$, the solution became yellow, and then methyl anthranilate was added. After having been stirred for $30 \mathrm{~min}$, the solution was acidified with $2 \mathrm{~N} \mathrm{HCl}$ and extracted with EtOAc. The organic phase was washed with water and brine, dried over $\mathrm{MgSO}_{4}$, and concentrated under reduced pressure. Purification by silica gel column chromatography (eluent: EtOAc/Hex $=1 / 1)$ gave 35c $(1.48 \mathrm{~g}, 79 \%)$ as white needles from EtOAc/Hex; mp 239-241 ${ }^{\circ} \mathrm{C} ;{ }^{1} \mathrm{H}-\mathrm{NMR}\left(500 \mathrm{MHz}, \mathrm{CDCl}_{3}\right) \delta: 10.09$ (br s, $\left.1 \mathrm{H}\right), 7.56(\mathrm{t}$, $1 \mathrm{H}, J=8.0 \mathrm{~Hz}), 7.45(\mathrm{t}, 1 \mathrm{H}, J=8.0 \mathrm{~Hz}), 7.28(\mathrm{~d}, 2 \mathrm{H}, J=8.0 \mathrm{~Hz}), 7.22(\mathrm{~d}, 1 \mathrm{H}$, $J=8.0 \mathrm{~Hz}), 6.86(\mathrm{~d}, 1 \mathrm{H}, J=8.0 \mathrm{~Hz}), 2.45(\mathrm{q}, 4 \mathrm{H}, J=7.5 \mathrm{~Hz}), 1.17(\mathrm{t}, 6 \mathrm{H}$, $J=7.5 \mathrm{~Hz}$ ); FAB-MS $m / z$ : $340(\mathrm{M}+\mathrm{H})^{+}$; Anal. Calcd for $\mathrm{C}_{18} \mathrm{H}_{17} \mathrm{~N}_{3} \mathrm{O}_{4}: \mathrm{C}$, 63.71; H, 5.05; N, 12.38: C, 63.65, H, 5.13; N, 12.34 .

General Procedure for Synthesis of Amino-Substituted PAQ-22 from Nitro-Substituted PAQ-22 Nitro-substituted PAQ-22 (35) was dissolved in EtOH and hydrogenated $\left(1\right.$ bar $\left.\mathrm{H}_{2}\right)$ over $10 \%$ palladium on charcoal. The mixture was filtered through a pad of Celite. The filtrate was evaporated to give the amino-substituted PA-22 (36).

6-Amino-3-(2,6-diethylphenyl)-2,4(1H,3H)-quinazolinedione (36a) According to the general procedure, $\mathbf{3 6}$ a was obtained in $79 \%$ yield as white needles from EtOAc; mp $258^{\circ} \mathrm{C} ;{ }^{1} \mathrm{H}-\mathrm{NMR}\left(500 \mathrm{MHz}, \mathrm{CDCl}_{3}\right) \delta$ : 8.56 (br s, $1 \mathrm{H}), 7.42$ (d, $1 \mathrm{H}, J=3.0 \mathrm{~Hz}), 7.39$ (t, $1 \mathrm{H}, J=8.0 \mathrm{~Hz}), 7.25$ (d, $2 \mathrm{H}, J=8.0 \mathrm{~Hz}$ ), $6.99(\mathrm{dd}, 1 \mathrm{H}, J=8.0,3.0 \mathrm{~Hz}), 6.84(\mathrm{~d}, 1 \mathrm{H}, J=8.0 \mathrm{~Hz}), 3.76(\mathrm{~s}, 2 \mathrm{H}), 2.45(\mathrm{q}$, $4 \mathrm{H}, J=8.0 \mathrm{~Hz}), 1.16(\mathrm{t}, 6 \mathrm{H}, J=8.0 \mathrm{~Hz})$; FAB-MS $m / z: 310(\mathrm{M}+\mathrm{H})^{+}$; Anal. Calcd for $\mathrm{C}_{18} \mathrm{H}_{19} \mathrm{~N}_{3} \mathrm{O}_{2}$ : C, 69.88; H, 6.19; N, 13.58: C, 69.63, H, 6.30; N, 13.32 .

7-Amino-3-(2,6-diethylphenyl)-2,4(1H,3H)-quinazolinedione (36b) According to the general procedure, $\mathbf{3 6} \mathbf{b}$ was obtained in quantitative yield as white needles from EtOAc; mp $275^{\circ} \mathrm{C} ;{ }^{1} \mathrm{H}-\mathrm{NMR}\left(500 \mathrm{MHz}, \mathrm{CDCl}_{3}\right) \delta$ : 8.89 (br s, 1H), 7.93 (d, 1H, J=8.5 Hz), 7.38 (t, 1H, $J=8.0 \mathrm{~Hz}), 7.24$ (d, 2H, $J=8.0 \mathrm{~Hz}), 6.49$ (d, 1H, $J=8.5 \mathrm{~Hz}), 6.13(\mathrm{br} \mathrm{s}, 1 \mathrm{H}), 2.46(\mathrm{q}, 4 \mathrm{H}, J=7.5 \mathrm{~Hz}$ ), $1.16(\mathrm{t}, 6 \mathrm{H}, J=7.5 \mathrm{~Hz})$; FAB-MS $m / z: 310(\mathrm{M}+\mathrm{H})^{+}$; Anal. Calcd for $\mathrm{C}_{18} \mathrm{H}_{19} \mathrm{~N}_{3} \mathrm{O}_{2}$ : C, 69.88; H, 6.19; N, 13.58: C, 69.73, H, 6.11; N, 13.81.

8-Amino-3-(2,6-diethylphenyl)-2,4(1H,3H)-quinazolinedione (36c) According to the general procedure, 36c was obtained in $95 \%$ yield as colorless needles from EtOAc/Hex; mp $245-250{ }^{\circ} \mathrm{C}$; ${ }^{1} \mathrm{H}-\mathrm{NMR}(500 \mathrm{MHz}$, $\left.\mathrm{CDCl}_{3}\right) \delta: 9.05(\mathrm{br} \mathrm{s}, 1 \mathrm{H}), 7.40(\mathrm{t}, 1 \mathrm{H}, J=7.5 \mathrm{~Hz}), 7.26(\mathrm{~d}, 2 \mathrm{H}, J=8.0 \mathrm{~Hz})$, $7.23(\mathrm{t}, 1 \mathrm{H}, J=8.0 \mathrm{~Hz}), 6.36(\mathrm{~d}, 1 \mathrm{H}, J=7.5 \mathrm{~Hz}), 6.13(\mathrm{~d}, 1 \mathrm{H}, J=7.5 \mathrm{~Hz}), 2.48$ (qd, 4H, $J=7.5,1.5 \mathrm{~Hz}), 1.18$ (t, $6 \mathrm{H}, J=7.5 \mathrm{~Hz}$ ); FAB-MS $m / z: 310$ $(\mathrm{M}+\mathrm{H})^{+}$; Anal. Calcd for $\mathrm{C}_{18} \mathrm{H}_{19} \mathrm{~N}_{3} \mathrm{O}_{2}: \mathrm{C}, 69.88 ; \mathrm{H}, 6.19 ; \mathrm{N}, 13.58: \mathrm{C}$, $69.75, \mathrm{H}, 6.22 ; \mathrm{N}, 13.41$. 
PN-22: 1-(2,6-Diethylphenyl) benzo[de]isoquinoline-1,3-dione (38) A mixture of 1,8-naphthalic anhydride $(198 \mathrm{mg}, 1 \mathrm{mmol})$ and 2,6-diethylaniline $(19)(149 \mathrm{mg}, 1 \mathrm{mmol})$ in $\mathrm{AcOH}(10 \mathrm{ml})$ was heated at $130^{\circ} \mathrm{C}$ for $20 \mathrm{~h}$. The reaction mixture was poured onto ice and this aqueous mixture was extracted with $\mathrm{CHCl}_{3}$. The organic layer was washed with water and brine, dried over $\mathrm{MgSO}_{4}$, and concentrated under reduced pressure. Purification by silica gel column chromatography (eluent: EtOAc/Hex: 1/1-2/1) gave 38 $(217 \mathrm{mg}, 66 \%)$ as colorless crystalline cubes from EtOAc; $\mathrm{mp} 235-237^{\circ} \mathrm{C}$; ${ }^{1} \mathrm{H}-\mathrm{NMR}\left(500 \mathrm{MHz}, \mathrm{CDCl}_{3}\right) \delta: 8.66(\mathrm{~d}, 2 \mathrm{H}, J=7.5 \mathrm{~Hz}), 8.29(\mathrm{~d}, 2 \mathrm{H}, J=7.5$ $\mathrm{Hz}), 7.81(\mathrm{t}, 1 \mathrm{H}, J=7.5 \mathrm{~Hz}), 7.41(\mathrm{t}, 2 \mathrm{H}, J=7.5 \mathrm{~Hz}), 7.28(\mathrm{~d}, 2 \mathrm{H}, J=7.5 \mathrm{~Hz})$, $2.47(\mathrm{q}, 4 \mathrm{H}, J=7.5 \mathrm{~Hz}), 1.14(\mathrm{t}, 6 \mathrm{H}, J=7.5 \mathrm{~Hz}) ;$ FAB-MS $\mathrm{m} / \mathrm{z}: 330$ $(\mathrm{M}+\mathrm{H})^{+}$; Anal. Calcd for $\mathrm{C}_{22} \mathrm{H}_{19} \mathrm{NO}_{3}: \mathrm{C}, 80.22 ; \mathrm{H}, 5.81 ; \mathrm{N}, 4.25: \mathrm{C}, 80.11$, $\mathrm{H}, 5.97 ; \mathrm{N}, 4.20$.

BAQ-33: 3-(4-Heptyl)-2,4(1H,3H)-quinazolinedione (39) To a mixture of 4-heptylamine $(116 \mathrm{mg}, 1.0 \mathrm{mmol})$ and $\mathrm{Et}_{3} \mathrm{~N}(1.0 \mathrm{mmol})$ in $1,2-$ dichloroethane $(10 \mathrm{ml})$ was added triphosgene $(0.40 \mathrm{mmol})$, and the resulting solution was heated at reflux for $30 \mathrm{~min}$. To the resulting mixture was added methyl anthranilate $(152 \mathrm{mg}, 1.0 \mathrm{mmol})$, and the mixture was stirred at reflux for another $1 \mathrm{~h}$. The solvent was removed under reduced pressure and the residue was dissolved in 1,4-dioxane $(5 \mathrm{ml})$ and $2 \mathrm{~N} \mathrm{NaOH}$ solution $(1$ $\mathrm{ml})$. The resulting solution was heated at $50^{\circ} \mathrm{C}$ for $12 \mathrm{~h}$. The reaction mixture was cooled, diluted with water, acidified with $2 \mathrm{~N} \mathrm{HCl}(c a .2 \mathrm{ml})$ and extracted with EtOAc. The organic layer was washed with water and brine, dried over $\mathrm{MgSO}_{4}$, and concentrated under reduced pressure. Purification by silica gel column chromatography (eluent: EtOAc/Hex: 1/4) gave $39(74 \mathrm{mg}$, $28 \%)$ as pale pink needles from EtOH; mp $112-114^{\circ} \mathrm{C} ;{ }^{1} \mathrm{H}-\mathrm{NMR}(500$ $\left.\mathrm{MHz}, \mathrm{CDCl}_{3}, 55^{\circ} \mathrm{C}\right) \delta: 10.28(\mathrm{brs}, 1 \mathrm{H}), 8.04(\mathrm{~d}, 1 \mathrm{H}, J=8.0 \mathrm{~Hz}), 7.50(\mathrm{td}$, $1 \mathrm{H}, J=8.0,1.0 \mathrm{~Hz}), 7.12(\mathrm{t}, 1 \mathrm{H}, J=8.0 \mathrm{~Hz}), 6.99(\mathrm{~d}, 1 \mathrm{H}, J=8.0 \mathrm{~Hz}), 5.03(\mathrm{br}$ $\mathrm{m}, 1 \mathrm{H}), 2.20-2.12(\mathrm{~m}, 2 \mathrm{H}), 1.73-1.65(\mathrm{~m}, 2 \mathrm{H}), 1.30-1.18(\mathrm{~m}, 4 \mathrm{H}), 0.85$ (t, $6 \mathrm{H}, J=8.0 \mathrm{~Hz})$; FAB-MS $m / z$ : $261(\mathrm{M}+\mathrm{H})^{+}$; Anal. Calcd for $\mathrm{C}_{15} \mathrm{H}_{20} \mathrm{~N}_{2} \mathrm{O}_{2}$ : C, 69.20; H, 7.74; N, 10.76. Found: C, 69.22; H, 7.74; N, 10.64 .

PAQ-00: (3-Phenyl-2,4(1H,3H)-quinazolinedione (40) According to the general procedure, $\mathbf{4 0}$ was obtained in $94 \%$ yield as white cubes from $\mathrm{EtOH} / \mathrm{CH}_{2} \mathrm{Cl}_{2} ; \mathrm{mp} 242-245^{\circ} \mathrm{C} ;{ }^{1} \mathrm{H}-\mathrm{NMR}\left(500 \mathrm{MHz}, \mathrm{CDCl}_{3}\right) \delta: 8.82(\mathrm{brs}$, $1 \mathrm{H}), 8.16(\mathrm{~d}, 1 \mathrm{H}, J=8.0 \mathrm{~Hz}), 7.62(\mathrm{t}, 1 \mathrm{H}, J=8.0 \mathrm{~Hz}), 7.54(\mathrm{t}, 2 \mathrm{H}, J=7.5 \mathrm{~Hz})$, $7.48(\mathrm{t}, 1 \mathrm{H}, J=7.5 \mathrm{~Hz}), 7.31(\mathrm{~d}, 2 \mathrm{H}, J=7.5 \mathrm{~Hz}), 7.25(\mathrm{t}, 1 \mathrm{H}, J=8.0 \mathrm{~Hz}), 6.99$ (d, $1 \mathrm{H}, J=8.0 \mathrm{~Hz})$; FAB-MS $m / z: 239(\mathrm{M}+\mathrm{H})$; Anal. Calcd for $\mathrm{C}_{14} \mathrm{H}_{10} \mathrm{~N}_{2} \mathrm{O}_{2}$ : C, 70.58; H, 4.23; N, 11.76. Found: C, 70.41; H, 4.46; N, 11.71 .

PAQ-11: 3-(2,6-Dimethylphenyl)-2,4(1H,3H)-quinazolinedione (41) According to the general procedure, $\mathbf{4 1}$ was obtained quantitatively as colorless crystalline cubes from EtOH; mp $211-214{ }^{\circ} \mathrm{C} ;{ }^{1} \mathrm{H}-\mathrm{NMR}(500 \mathrm{MHz}$, $\mathrm{CDCl}_{3}$ ) $\delta: 10.09($ br s, $1 \mathrm{H}), 8.14(\mathrm{dd}, 1 \mathrm{H}, J=7.5,1.0 \mathrm{~Hz}), 7.46(\mathrm{td}, 1 \mathrm{H}$, $J=7.5,1.0 \mathrm{~Hz}), 7.32(\mathrm{t}, 1 \mathrm{H}, J=7.5 \mathrm{~Hz}), 7.23(\mathrm{~d}, 2 \mathrm{H}, J=8.0 \mathrm{~Hz}), 7.21(\mathrm{t}, 1 \mathrm{H}$, $J=7.5 \mathrm{~Hz}), 6.68(\mathrm{~d}, 1 \mathrm{H}, J=8.0 \mathrm{~Hz}), 2.17(\mathrm{~s}, 6 \mathrm{H}):$ FAB-MS $\mathrm{m} / \mathrm{z}: 267$ $(\mathrm{M}+\mathrm{H})^{+}$; Anal. Caled for $\mathrm{C}_{16} \mathrm{H}_{14} \mathrm{~N}_{2} \mathrm{O}_{2}$ : C, 72.16; H, 5.30; N, 10.52. Found: C, 72.28; H, 5.49; N, 10.49 .

PAQ-33: 3-(2,6-Diisopropylphenyl)-2,4(1H,3H)-quinazolinedione (42) According to the general procedure, $\mathbf{4 2}$ was obtained in $97 \%$ yield as colorless needles from $\mathrm{EtOH} / \mathrm{H}_{2} \mathrm{O}$; mp $245-248^{\circ} \mathrm{C}$; ${ }^{1} \mathrm{H}-\mathrm{NMR}(500 \mathrm{MHz}$, $\left.\mathrm{CDCl}_{3}\right) \delta: 8.36($ br s, $1 \mathrm{H}), 8.19(\mathrm{~d}, 1 \mathrm{H}, J=8.0 \mathrm{~Hz}), 7.65(\mathrm{t}, 1 \mathrm{H}, J=8.0 \mathrm{~Hz})$, $7.46(\mathrm{t}, 1 \mathrm{H}, J=8.0 \mathrm{~Hz}), 7.30$ (d, $2 \mathrm{H}, J=8.0 \mathrm{~Hz}), 7.27(\mathrm{t}, 1 \mathrm{H}, J=8.0 \mathrm{~Hz}), 7.03$ $(\mathrm{d}, 1 \mathrm{H}, J=8.0 \mathrm{~Hz}), 2.70(\mathrm{qq}, 2 \mathrm{H}, J=7.0,7.0 \mathrm{~Hz}), 1.19(\mathrm{~d}, 6 \mathrm{H}, J=7.0 \mathrm{~Hz})$, $1.16(\mathrm{~d}, 6 \mathrm{H}, J=7.0 \mathrm{~Hz})$; FAB-MS $m / z: 323(\mathrm{M}+\mathrm{H})^{+}$; Anal. Calcd for $\mathrm{C}_{20} \mathrm{H}_{22} \mathrm{~N}_{2} \mathrm{O}_{2}: \mathrm{C}, 74.51 ; \mathrm{H}, 6.88 ; \mathrm{N}, 8.69$. Found: C, 74.41; H, 7.00; N, 8.72.

3-(2,6-Dimethoxyphenyl)-2,4(1H,3H)-quinazolinedione (43) According to the general procedure, $\mathbf{4 3}$ was obtained as colorless crystalline cubes from EtOAc/Hex; mp $>300{ }^{\circ} \mathrm{C} ;{ }^{1} \mathrm{H}-\mathrm{NMR}\left(500 \mathrm{MHz}, \mathrm{CDCl}_{3}\right) \delta: 8.15(\mathrm{~d}, 1 \mathrm{H}$, $J=8.0 \mathrm{~Hz}), 7.88(\mathrm{brd}, 1 \mathrm{H}), 7.60(\mathrm{t}, 1 \mathrm{H}, J=8.0 \mathrm{~Hz}), 7.35(\mathrm{t}, 1 \mathrm{H}, J=8.0 \mathrm{~Hz})$, $7.22(\mathrm{t}, 1 \mathrm{H}, J=8.0 \mathrm{~Hz}), 6.99(\mathrm{~d}, 2 \mathrm{H}, J=8.0 \mathrm{~Hz}), 3.77$ (br s, $6 \mathrm{H})$; FAB-MS m/z: $299(\mathrm{M}+\mathrm{H})^{+}$; Anal. Calcd for $\mathrm{C}_{16} \mathrm{H}_{14} \mathrm{~N}_{2} \mathrm{O}_{4}$ : C, 64.42; H, 4.73; N, 9.39. Found: C, 64.31; H, 4.86; N, 9.37.

3-(1-Naphthyl)-2,4(1H,3H)-quinazolinedione (44) According to the general procedure, $\mathbf{4 4}$ was obtained in $73 \%$ yield as colorless plates from $\mathrm{MeOH} / \mathrm{EtOAc} ; \mathrm{mp} 280-283{ }^{\circ} \mathrm{C} ;{ }^{1} \mathrm{H}-\mathrm{NMR}\left(500 \mathrm{MHz}, \mathrm{CDCl}_{3}\right) \delta$ : 9.37 (s, $1 \mathrm{H}), 8.15(\mathrm{~d}, 1 \mathrm{H}, J=8.0 \mathrm{~Hz}), 8.01(\mathrm{~d}, 1 \mathrm{H}, J=8.0 \mathrm{~Hz}), 7.96(\mathrm{~d}, 1 \mathrm{H}, J=8.0$ $\mathrm{Hz}), 7.63(\mathrm{t}, 1 \mathrm{H}, J=8.0 \mathrm{~Hz}), 7.62(\mathrm{~d}, 1 \mathrm{H}, J=8.0 \mathrm{~Hz}), 7.54-7.46(\mathrm{~m}, 4 \mathrm{H})$, $7.24(\mathrm{t}, 1 \mathrm{H}, J=8.0 \mathrm{~Hz}), 6.82(\mathrm{~d}, 1 \mathrm{H}, J=8.0 \mathrm{~Hz}) ;$ FAB-MS $m / z: 289(\mathrm{M}+\mathrm{H})^{+}$; Anal. Calcd for $\mathrm{C}_{18} \mathrm{H}_{12} \mathrm{~N}_{2} \mathrm{O}_{2}$ : C, 74.99; H, 4.20; N, 9.72. Found: C, 74.89; H, $4.50 ; \mathrm{N}, 9,89$.

3-(2-Methoxy-1-naphthyl)-2,4(1H,3H)-quinazolinedione (45) According to the general procedure, $\mathbf{4 5}$ was obtained in $45 \%$ yield as a pale pink powder from EtOAc; mp $275-278^{\circ} \mathrm{C}$; ${ }^{1} \mathrm{H}-\mathrm{NMR}\left(500 \mathrm{MHz}, d_{6}\right.$ DMSO) $\delta: 11.65(\mathrm{~s}, 1 \mathrm{H}), 8.08(\mathrm{~d}, 1 \mathrm{H}, J=8.0 \mathrm{~Hz}), 7.96(\mathrm{~d}, 1 \mathrm{H}, J=8.0 \mathrm{~Hz})$, 7.94 (d, $1 \mathrm{H}, J=8.0 \mathrm{~Hz}), 7.75$ (td, $1 \mathrm{H}, J=8.0,1.0 \mathrm{~Hz}), 7.59$ (d, $1 \mathrm{H}, J=8.0$
$\mathrm{Hz}), 7.54$ (d, $1 \mathrm{H}, J=8.0 \mathrm{~Hz}), 7.44(\mathrm{td}, 1 \mathrm{H}, J=8.0,2.0 \mathrm{~Hz}), 7.40$ (td, $1 \mathrm{H}$, $J=8.0,2.0 \mathrm{~Hz}), 7.29(\mathrm{~d}, 1 \mathrm{H}, J=8.0 \mathrm{~Hz}), 7.26(\mathrm{t}, 1 \mathrm{H}, J=8.0 \mathrm{~Hz}), 3.88(\mathrm{~s}, 3 \mathrm{H})$; FAB-MS $m / z$ : $319(\mathrm{M}+\mathrm{H})^{+}$; Anal. Calcd for $\mathrm{C}_{19} \mathrm{H}_{14} \mathrm{~N}_{2} \mathrm{O}_{3}$ : C, 71.69; H, 4.43; N, 8.80. Found: C, 71.39; H, 4.63; N, 8.66.

Cells MOLT- 4 cells were maintained in an RPMI1640 medium supplemented with $10 \% \mathrm{v} / \mathrm{v}$ fetal bovine serum at $37^{\circ} \mathrm{C}$ under a $5 \% \mathrm{CO}_{2}$ atmosphere.

Assay of Enzyme Activity Neutral aminopeptidase activity was evaluated in the usual assay by measuring 7-amino-4-methylcoumarin (AMC) liberated from L-methylcoumarylamide (Ala-AMC) ${ }^{12,13)}$ Briefly, to a solution of $800 \mu \mathrm{l}$ of $50 \mathrm{~mm}$ Tris- $\mathrm{HCl}(\mathrm{pH} 7.4)$, in the presence or absence of a test inhibitor (various concentrations), was added intact cell suspension $\left(2 \times 10^{6}\right.$ cells $/ \mathrm{ml}$ ) at $37^{\circ} \mathrm{C}$ for exactly $10 \mathrm{~min}$ for pre-incubation. To this solution was added $1 \mathrm{ml}$ of Ala-AMC $(1 \mathrm{~mm})$ at $37^{\circ} \mathrm{C}$ for exactly $30 \mathrm{~min}$. Then, $3 \mathrm{ml}$ of $1 \mathrm{~m}$ AcONa-AcOH (pH 4.0) was added to stop the enzymatic reaction. The amounts of liberated AMC were measured in terms of fluorescence intensity (excitation at $380 \mathrm{~nm}$, emission at $420 \mathrm{~nm}$ ). The assay was performed at least in duplicate, and the mean value was taken. Though the values deviated from experiment to experiment, the results (order of potency) were basically reproducible, and a typical set of data is shown in the tables.

Cytotoxicity Assay Test compounds were dissolved in DMSO at 20, 2 and $0.2 \mathrm{~mm}$. A $5 \mu \mathrm{l}$ aliquot of each solution was added to $100 \mu \mathrm{l}$ of MOLT- 4 cell suspension and $400 \mu$ l of RPMI1640 in 24-well plates, in which the cell concentration was about $1 \times 10^{5}$ cells $/ \mathrm{ml}$; the final DMSO concentration was kept below $0.5 \%$. Control samples received the same volume of DMSO alone. The cells were incubated for $3 \mathrm{~d}$ at $37^{\circ} \mathrm{C}$ under a $5 \% \mathrm{CO}_{2}$ atmosphere. Cytotoxicity was evaluated in terms of the amounts of lactose dehydrogenase (LDH) produced by cyto Tox $96^{\mathrm{TM}}$. The results are shown as relative values of LDH to the control (DMSO only; taken as 1).

Proliferation-Inhibitory Activity Conditions for assay of the proliferation-inhibitory activity were the same as described above. Proliferation-inhibitory activity was evaluated by counting cells with WST-1. The results are shown as relative values of numbers of cells to that of a control (DMSO only; taken as 1).

Cell Invasion Assay Tumor cell invasion was assessed by counting mouse metastatic tumor cells (B16F10/L5 mouse melanoma cells) that invaded Matrigel-coated filters, according to Albini et al. ${ }^{49)}$ Briefly, an invasion chamber, whose upper filter surface is coated with Matrigel (Becton Dickinson), was soaked in a 12-well plate having $500 \mu 1$ well of RPMI cellconditioned medium containing $10 \%$ BSA and human plasma fibronectin 20 $\mu \mathrm{g} / \mathrm{ml}$. B16F10/L5 cells $\left(2.0 \times 10^{5}\right.$ cells $/ \mathrm{ml}$ in $200 \mu \mathrm{l}$ of RPMI containing $0.1 \%$ BSA ) were added to the upper part of the chamber. The cells were incubated for $24 \mathrm{~h}$ at $37^{\circ} \mathrm{C}$ under a $5 \% \mathrm{CO}_{2}$ atmosphere in the presence or absence of the test compounds. After incubation, cells present in the lower part of the cell chamber and on the lower surface of the filter (stained with Crystal violet after careful removal of the cells on the upper surface of the filter by wiping with cotton swabs) were counted manually under a microscope. Each sample was tested in triplicate, and the mean values are shown.

Acknowledgment The work described in this paper was partially supported by Grants-in-Aid for Scientific Research from The Ministry of Education, Culture, Sports, Science and Technology, Japan.

\section{References and Notes}

1) Filder I. J., Gersten D. M., Hart I. R., Adv. Cancer Res., 28, 149-250 (1978).

2) Liotta 1. A., Tryggvason K., Garbisa S., Hart I., Foltz C. M., Shafie S., Nature (London), 284, 67-68 (1980).

3) Liotta 1. A., Goldfarb R. H., Brundage R., Siegel G. P., Terenova V., Garbisa S., Cancer Res., 41, 4629-4636 (1981).

4) Sloane B. F., Honn K. V., Sadler J. G., Cancer Res., 42, 980-986 (1982).

5) Nagaoka I., Tamashita T., Biochim. Biophys. Acta, 598, 169-172 (1987)

6) Yoneda J., Saiki I., Fujii H., Abe F., Kojima Y., Azuma I., Clin. Exp. Metastasis, 10, 49-59 (1992).

7) Tsuruo T., Nagamura K., Iida H., Yamori T., Tsukagoshi S., Sakurai Y., J. Antibiot., 34, 1206-1209 (1981).

8) Saiki I., Murata J., Watanabe K., Fujii H., Abe F., Azuma I., Jpn. J. Cancer Res., 80, 873-878 (1989).

9) Look A. T., Ashmun R. A., Shapiro L. H., Peiper S. C., J. Clin. Invest., 83, 1299-1307 (1989).

10) Bowes M. A., Kenny A. J., J. Immunol., 60, 247-253 (1987).

11) Saiki I., Fujii H., Yoneda J., Abe F., Nakajima M., Tsuruo T., Azuma 
I., Int. J. Cancer, 54, 137-143 (1993).

12) Fujii H., Nakajima M., Aoyagi T., Tsuruo T., Biol. Pharm. Bull., 19, 6-10 (1996).

13) Umezawa H., Aoyagi T., Suda H., Hamada M., Takeuchi T., J. Antibiot., 29, 97-99 (1976).

14) Nicolson G. L., Cancer Res., 47, 1473-1487 (1987).

15) Moscattelli D., Rifkin D. B., Biochim. Biophys. Acta, 948, 67-85 (1988).

16) Hashimoto Y., Curr. Med. Chem., 5, 163-178 (1998).

17) Miyachi H., Azuma A., Kitamoto T., Hayashi K., Kato S., Koga M., Sato B., Hashimoto Y., Bioorg. Med. Chem. Lett., 7, 1483-1488 (1997).

18) Miyachi H., Azuma A., Hashimoto Y., Yakugaku Zasshi, 117, 91-107 (1997).

19) Hashimoto Y., Recent Res. Develop. Org. Chem., 4, 87-120 (2000).

20) Kakuta H., Takahashi H., Sou S., Kita T., Nagasawa K., Hashimoto Y., Recent Res. Devel. Medicinal Chem., 1, 189-211 (2001).

21) Kagechika H., Komoda M., Fujimoto Y., Koiso Y., Takayama H., Kadoya S., Miyata K., Kato F., Kato M., Hashimoto Y., Biol. Pharm. Bull., 22, 1010-1012 (1999).

22) Shimazawa R., Miyachi H., Takayama H., Kuroda K., Kato F., Kato M., Hashimoto Y., Biol. Pharm. Bull., 22, 224-226 (1999).

23) Miyachi H., Kato M., Kato F., Hashimoto Y., J. Med. Chem., 41, 263-265 (1998).

24) Shimazawa R., Takayama H., Hashimoto Y., Jpn. J. Synth. Org. Chem., 57, 92-104 (1999).

25) Shimazawa R., Takayama H., Fujimoto Y., Komoda M., Dodo K., Yamasaki R., Shirai R., Koiso Y., Miyata K., Kato F., Kato M., Miyachi H., Hashimoto Y., J. Enzyme Inhibit., 14, 259-275 (1999).

26) Takahashi H., Komoda M., Kakuta H., Hashimoto Y., Yakugaku Zasshi, 120, 909-921 (2000).

27) Komoda M., Kakuta H., Takahashi H., Fujimoto Y., Kadoya S., Kato F., Hashimoto Y., Bioorg. Med. Chem., 9, 121-131 (2001).

28) Hersh L. B., McKelvy J. F., J. Neurochem., 36, 171-178 (1981).

29) Bauer W. O., Nanda I., Beck G., Schmid M., Jacob F., Cytogenet. Cell Genet., 92, 221-224 (2001).

30) Tobler A. R., Constam D. B., Schmitt-Graff A., Malipiero U., Schlabach R., Fontana A., J. Neurochem., 68, 889-897 (1997).

31) Johnson G. D., Hersh L. B., Arch. Biochem. Biophys., 276, 305-309 (1990).

32) Rawlings N. D., Barrett A. J., Biochem. J., 290, 205-218 (1993).
33) McLellan S., Dyer S. H., Rodriguenz G., Hersh L.B., J. Neurochem., 51, 1552-1559 (1988).

34) Constam D. B., Tobler A. R., Rensing-Ehl A., Kemler I., Hersh L. B., Fontana A., J. Biol. Chem., 270, $26931-26939$ (1995).

35) de Gandarias J. M., Irazusta J., Gil J., Fernandez D., Varona A., Casis L., Brain Res. Bull., 50, 283-290 (1999).

36) Osada T., Ikegami S., Takiguchi-Hayashi K., Yamazaki Y., KatohFukui Y., Higashinakagawa T., Sasaki Y., Takeuchi Y., J. Neurochem. 19, 6068-6078 (1999).

37) Kakuta H., Koiso Y., Takahashi H., Nagasawa K., Hashimoto Y., Heterocycles, 55, 1433-1438 (2001).

38) Kakuta H., Koiso Y., Nagasawa K., Hashimoto Y., Bioorg. Med. Chem. Lett., 13, 83-86 (2003).

39) Mallamo J. P., Pilling G. M., Wetzel J. R., Kowalczik P. J., Bell M. R., Kullnig R. K., Batzold F. H., Juniewiecz P. E., Winnecker R. C., Luss H. R., J. Med. Chem., 35, 1663-1670 (1992).

40) Kollman P., McKelvey J., Johansson A., Rothenberg S., J. Amer. Chem. Soc., 97, 955-965 (1975).

41) Weiner P. K., Langridge R., Blaney J. M., Schaefer R., Kollman P. A., Proc. Natl. Acad. Sci. U.S.A., 79, 3754-3758 (1982).

42) Naray-Szabo G., J. Mol. Graphics, 7, 76-81 (1989).

43) Rashkin M. J., Waters M. L., J. Amer. Chem. Soc., 124, 1860-1861 (2002).

44) Electrostatic potential surfaces were generated by mapping PM3 electrostatic potentials onto the surfaces of molecular electron density using Spartan (Wavefunction, Inc. Irvine, CA, U.S.A.). Potential energy range is $-50-50 \mathrm{kcal} / \mathrm{mol}$ for all surfaces shown. Red indicates areas of greater electron density and blue indicates areas of less electron density.

45) Papadopoulas E. P., Torres C. D., J. Heterocycl. Chem., 19, 269-272 (1982).

46) Brown F. J., Bernstain P. R., Cronk L. A., Dosset D. L., Hebbel K. C., Maduskuie T. P., Jr., Shapiro H. S., Vacek E. P., Yee Y. K., Willard A. K., Krell R. D., Snyder D. W., J. Med. Chem., 32, 807-826 (1989).

47) Canonne P., Akssira M., Dahdouh A., Kasmi H., Boumzebra M., Heterocycles, 36, 1305-1313 (1993).

48) Sekine K., Fujii H., Abe F., Nishikawa K., Int. J. Cancer, 94, 485491 (2001).

49) Albini A., Iwamoto Y., Kleinman H. K., Martin G. R., Aaronson S. A., Kozlowski J. M., McEwan R. N., Cancer Res., 47, 3239-3245 (1997). 